\title{
Understanding Mn-Based Intercalation Cathodes from Thermodynamics and Kinetics
}

\author{
Yin Xie ${ }^{1}$, Yongcheng Jin ${ }^{2, *}$ and Lan Xiang ${ }^{1, *}$ \\ 1 Department of Chemical Engineering, Tsinghua University, Beijing 100084, China; \\ xiey16@mails.tsinghua.edu.cn \\ 2 Qingdao Institute of bioenergy and bioprocess technology, Chinese Academy of Sciences, \\ Qingdao 266101, China \\ * Correspondence: jinyc@qibebt.ac.cn (Y.J.); xianglan@mail.tsinghua.edu.cn (L.X.); \\ Tel./Fax: +86-532-8066-2703 (Y.J.); Tel.: +86-10-6278-8984 (L.X.); Fax: +86-10-6277-2051 (L.X.)
}

Academic Editor: Helmut Cölfen

Received: 24 June 2017; Accepted: 11 July 2017; Published: 13 July 2017

\begin{abstract}
A series of Mn-based intercalation compounds have been applied as the cathode materials of Li-ion batteries, such as $\mathrm{LiMn}_{2} \mathrm{O}_{4}, \mathrm{LiNi}_{1-\mathrm{x}-\mathrm{y}} \mathrm{Co}_{\mathrm{x}} \mathrm{Mn}_{\mathrm{y}} \mathrm{O}_{2}$, etc. With open structures, intercalation compounds exhibit a wide variety of thermodynamic and kinetic properties depending on their crystal structures, host chemistries, etc. Understanding these materials from thermodynamic and kinetic points of view can facilitate the exploration of cathodes with better electrochemical performances. This article reviews the current available thermodynamic and kinetic knowledge on Mn-based intercalation compounds, including the thermal stability, structural intrinsic features, involved redox couples, phase transformations as well as the electrical and ionic conductivity.
\end{abstract}

Keywords: lithium battery; Mn-based cathodes; thermodynamics; kinetics

\section{Introduction}

Lithium-ion batteries have contributed to the popularization of portable electronic products during past two decades, and now demonstrated great potential in the fields of electric vehicles, smart electrical grids, etc. Among various cathode materials, Mn-based intercalation compounds have received much attention owing to their high nature abundance, low price as well as the excellent performances in electrochemical energy storage and conversion. From the aspect of element, Mn plays an important role in intercalation cathodes. As a variable valency element, Mn may provide two-electron process to obtain higher capacity [1], and ions with different valence exhibit varied kinetic properties, influencing the cycling performance of electrode [2-4]. As one of the transition metal (TM) elements in active cathode materials, Mn can act as either the structural stabilizer such as in $\mathrm{LiNi}_{1-x-y} \mathrm{Co}_{x} \mathrm{Mn}_{y} \mathrm{O}_{2}$ (NCM) [3] or the active center such as $\mathrm{LiMn}_{2} \mathrm{O}_{4}$. Especially, in Li-rich layered oxides, $\mathrm{Li}_{2} \mathrm{MnO}_{3}$ not only acts as a unit of structural stabilizer but also becomes a major contributor to the increased capacity after its activation process [5]. Therefore, it is necessary to discuss Mn-based intercalation cathodes.

Though most Mn-based cathodes have their advantages, several drawbacks still limit their application in high-energy storage devices. For example, Li-rich layered oxides exhibit high capacities, such as $250-300 \mathrm{~mA} \mathrm{~h} \mathrm{~g}^{-1}$ [6], however, problems of the capacity decay, voltage fading and hysteresis became obstacles to its commercialization. These disadvantages are rooted in their crystal structures and chemistries, such as the Jahn-Teller (JT) effect caused by $\mathrm{Mn}^{3+}$, interactions between spin moments, disproportionation reactions of $\mathrm{Mn}^{3+}$, ion mobility, the dimensions of structure, etc.

There are few reviews of Mn-based intercalation cathodes from the thermodynamic and kinetic points of view. This article focuses on the understanding the electrochemical performances of Mn-based 
cathodes from these two aspects. Firstly, the thermodynamic-related aspects are discussed, including the thermal stability, structural features, redox couples as well as the phase transformations. Then, the kinetic behaviors are reviewed, including electrical and ionic conductivity and the motion of cations.

\section{Thermodynamics}

\subsection{Before Electrochemical Cycles}

\subsubsection{Theoretical Capacity}

The theoretical capacity of a given electrode material can be obtained by the following equation:

$$
Q=\frac{n \times N_{A}}{M \times 3.6}
$$

where $Q$ is the theoretical specific capacity, $\mathrm{mA} \mathrm{h} \mathrm{g}^{-1} ; M$ is the molar mass of the active material, $\mathrm{g} \mathrm{mol}^{-1}$; $n$ represents the number of electrons involved in the reaction; and $N_{A}$ is the Avogadro's number.

Generally, practical capacity is lower than the theoretical value, due to the occurrence of oxygen loss or irreversible phase change at low lithium content and high voltage [7]. The theoretical and practical capacities of several Mn-based cathodes are listed in Table 1.

Table 1. The specific capacity of several Mn-based cathodes.

\begin{tabular}{cccc}
\hline Compounds & $\begin{array}{c}\text { Theoretical Capacity } \\
\left(\mathbf{m} \mathbf{~ h ~} \mathbf{~ g}^{-\mathbf{1}}\right)\end{array}$ & $\begin{array}{c}\text { Experimental Capacity } \\
\left(\mathbf{m} \mathbf{A} \mathbf{~ h ~} \mathbf{~}^{-\mathbf{1}} \mathbf{)}\right.\end{array}$ & References \\
\hline $\mathrm{Li}\left(\mathrm{Ni}_{1-\mathrm{x}-\mathrm{y}} \mathrm{Co}_{\mathrm{x}} \mathrm{Mn}_{\mathrm{y}}\right) \mathrm{O}_{2}$ & $\sim 285$ & $150 \sim 210$ & {$[5]$} \\
$\mathrm{xLi} \mathrm{MnO}_{3} \cdot(1-\mathrm{x}) \mathrm{LiMO}_{2}$ & $\sim 280$ & $250 \sim 300$ & {$[8,9]$} \\
$\mathrm{LiMn}_{2} \mathrm{O}_{4}$ & 148 & $120(\mathrm{C} / 10)$ & {$[10]$} \\
$\mathrm{LiNi}_{0.5} \mathrm{Mn}_{1.5} \mathrm{O}_{4}$ & 147 & $146(\mathrm{C} / 20)$ & {$[11]$} \\
$\mathrm{Li}_{4} \mathrm{Mn}_{2} \mathrm{O}_{5}$ & 492 & $355(\mathrm{C} / 20)$ & {$[1]$} \\
\hline
\end{tabular}

\subsubsection{Thermal Stability}

Thermal stability is required to be concerned for the following two reasons: firstly, the safety. Most cathode materials, especially delithiated phases, go through an exothermic/endothermic process accompanied by oxygen release or phase changes during heat treatment [4]. In the presence of electrolyte, the highly exothermic reactions of electrolyte with oxygen make the total reaction exothermic, even if the oxygen-release reactions of the cathode are endothermic [12]. These reactions are believed to be serious safety risks. Secondly, the knowledge obtained from thermal behavior studies can provide useful information for predicting the structure evolution during long-term electrochemical cycling [4]. For example, the lithium-rich layered oxides go through a structure transformation from layered to spinel during electrochemical processes, which is already observed in the thermal decomposition process at the initial stage of heating $[13,14]$. Thermal stability of cathodes is affected by many factors, such as the structure instinct stability at a certain temperature [12], the strength of TM-O bond [15], crystal field stabilization energy [4,12], etc., which will be discussed in the following part.

- Layered Mn-based Oxides

For most layered cathode materials, oxygen-release at high temperatures is common. One example is $\mathrm{LiNi}_{1-x-y} \mathrm{Co}_{\mathrm{x}} \mathrm{Mn}_{\mathrm{y}} \mathrm{O}_{2}$, which is intensively studied by Noh et al. [5]. All samples have weight loss under heating attributed to the oxygen release during phase transitions (from layered $R \overline{3} \mathrm{~m}$ to spinel $\mathrm{Fd} 3 \mathrm{~m}$ ). In addition, the onset temperatures shift to lower side with increasing Ni content, as a result of the reduced structural stability.

Another example is the better thermal stability of charged $\mathrm{Li}_{x} \mathrm{Ni}_{1 / 3} \mathrm{Co}_{1 / 3} \mathrm{Mn}_{1 / 3} \mathrm{O}_{2}$ than $\mathrm{Li}_{\mathrm{x}} \mathrm{Ni}_{0.8} \mathrm{Co}_{0.15} \mathrm{Al}_{0.05} \mathrm{O}_{2}[16,17]$. This can be explained as the different structural transformation during 
heating. In the case of $\mathrm{Li}_{0.55}\left(\mathrm{Ni}_{1 / 3} \mathrm{Co}_{1 / 3} \mathrm{Mn}_{1 / 3}\right) \mathrm{O}_{2}$, the formation of a stable spinel phase causes less structural disorder, while, for $\mathrm{Li}_{0.45}\left(\mathrm{Ni}_{0.8} \mathrm{Co}_{0.15} \mathrm{Al}_{0.05}\right) \mathrm{O}_{2}$, the formation of a thermodynamically unstable spinel phase exacerbates the release of oxygen [16].

From the above examples, one can see that oxygen evolution at high temperatures is unavoidable for charged oxides, which can be understood from a thermodynamic point of view: (1) cations with high valence state, such as $\mathrm{Ni}^{4+}$ and $\mathrm{Co}^{4+}$, have a strong reduction tendency; (2) the delithiated compounds become unstable as predicted in phase diagram; and (3) reaction that releases $\mathrm{O}_{2}$ gas has a large positive entropy and can always occur at a high enough temperature $[4,12]$.

Phase changes during heating are companied by the movement of transition metal (TM) ions, as a result, thermal stability of cathodes is significantly affected by the ease of TM migration, which will be discussed in Section 3.2.3. Using cations that prefer to occupy $\mathrm{T}_{\mathrm{d}}$ sites can stabilize the structure at the initial stage of heating, and hence the overall thermal stability of materials can be improved [4].

- Spinel-type Mn-based Oxides

At high temperatures, the decomposition of $\mathrm{LiMn}_{2} \mathrm{O}_{4}$ follows the reaction below [12]:

$$
\mathrm{LiMn}_{2} \mathrm{O}_{4} \rightarrow \mathrm{LiMnO}_{2}+\frac{1}{3} \mathrm{Mn}_{3} \mathrm{O}_{4}+\frac{1}{3} \mathrm{O}_{2}
$$

The reaction enthalpy is $0.984 \mathrm{eV}$ per formula unit of $\mathrm{LiMn}_{2} \mathrm{O}_{4}$, which indicates a highly endothermic process. As a result, in contrast to $\mathrm{Li}_{x} \mathrm{NiO}_{2}$ and $\mathrm{Li}_{\mathrm{x}} \mathrm{CoO}_{2}, \mathrm{LiMn}_{2} \mathrm{O}_{4}$ is thermodynamically stable at common conditions [12].

The cation-substituted spinel oxides $\mathrm{LiM}_{\mathrm{x}} \mathrm{Mn}_{2-\mathrm{x}} \mathrm{O}_{4}(\mathrm{M}=\mathrm{Ni}, \mathrm{Co}, \mathrm{Fe}, \mathrm{Cr}, \mathrm{Mg}, \mathrm{Al}, \mathrm{Ti}, \mathrm{Cu}, \mathrm{Zn}$, etc.) have different thermal stability from $\mathrm{LiMn}_{2} \mathrm{O}_{4}$. Among all doped compounds, $\mathrm{LiNi}_{0.5} \mathrm{Mn}_{1.5} \mathrm{O}_{4}$ is one of the most attractive materials with a flat voltage plateau at $4.7 \mathrm{~V}$, which can either form the disordered phase (space group Fd $3 \mathrm{~m}$ ) or the ordered phase (space group $\mathrm{P}_{3} 32$ ). The disordered phase exhibits slightly poor thermal stability than the ordered one [4], due to the formation of Ni-rich and Ni-poor domains in the disordered compound, leading to two Jahn-Teller-distorted tetragonal phases with different Ni-Mn ratios [18]. In addition, nickel doping reduces the decomposition temperature, since the $\mathrm{Ni}^{2+}-\mathrm{O}$ bond is weaker than the $\mathrm{Mn}^{4+}-\mathrm{O}$ bond, resulting in a lower activation energy barrier for thermal decomposition [15]. The effect of other dopants can also be explained by the nature of the substituent cations and the metal-oxygen bond strength $[15,19]$.

In summary, the decomposition temperatures of several materials are listed in Table 2.

Table 2. Decomposition temperatures of several Mn-based oxides.

\begin{tabular}{ccc}
\hline Compounds & Onset Temperatures of Decomposition $\left({ }^{\circ} \mathrm{C}\right)$ & Reference \\
\hline $\mathrm{Li}_{0.45}\left(\mathrm{Ni}_{0.8} \mathrm{Co}_{0.15} \mathrm{Al}_{0.05}\right) \mathrm{O}_{2}$ & 190 & {$[16]$} \\
$\mathrm{Li}_{0.55}\left(\mathrm{Ni}_{1 / 3} \mathrm{Co}_{1 / 3} \mathrm{Mn}_{1 / 3}\right) \mathrm{O}_{2}$ & 250 & {$[16]$} \\
$0.22 \mathrm{Li}_{2} \mathrm{MnO}_{3} \cdot 0.78 \mathrm{Li}_{\left(1 \mathrm{Mn}_{0.143} \mathrm{Ni}_{0.429} \mathrm{Co}_{0.429}\right) \mathrm{O}_{2}}$ & 275 & {$[20]$} \\
$\mathrm{LiNi}_{0.5} \mathrm{Mn}_{1.5} \mathrm{O}_{4}$ (ordered) & 300 & {$[4]$} \\
$\mathrm{LiNi}_{0.5} \mathrm{Mn}_{1.5} \mathrm{O}_{4}$ (disordered) & 240 & {$[4]$} \\
$\mathrm{LiMn}_{2} \mathrm{O}_{4}$ & 600 & {$[21]$} \\
$\mathrm{Li}_{\mathrm{x}} \mathrm{Mn}_{2} \mathrm{O}_{4}$ & $152 \sim 200$ & {$[22]$} \\
\hline
\end{tabular}

\subsubsection{Pristine Structures and Their Formation}

The cycling performances of rechargeable Li-ion batteries also greatly depend on the structural integrity of the host materials during electrochemical processes [23]. Therefore, the structures of electrode materials are important. Table 3 summarizes the structures of several Mn-based cathodes for Li-ion batteries. 
Table 3. Several crystal structures of Mn-based cathodes.

\begin{tabular}{ccccc}
\hline Type & Compounds & Symmetry & Space Group & Reference \\
\hline \multirow{4}{*}{ Layered } & $\mathrm{LiMnO}_{2}$ & orthorhombic & $\mathrm{Pmmn}$ & {$[24]$} \\
& $\mathrm{Li}\left(\mathrm{Ni}_{1-\mathrm{x}-\mathrm{y}} \mathrm{Co}_{\mathbf{x}} \mathrm{Mn}_{\mathrm{y}}\right) \mathrm{O}_{2}$ & Monoclinic & $\mathrm{C} 2 / \mathrm{m}$ & {$[25]$} \\
& $\mathrm{LiMn}_{2} \mathrm{O}_{3}$ & Hexagonal & $\mathrm{R} \overline{\mathrm{m}}$ & {$[26]$} \\
& $\mathrm{xLi} \mathrm{MnO}_{3} \cdot(1-\mathrm{x}) \mathrm{LiMO}_{2}$ & monoclinic & $\mathrm{C} 2 / \mathrm{m}$ & {$[27]$} \\
Spinel & $\mathrm{LiMn}_{2} \mathrm{O}_{4}$ & Cubic & $\mathrm{R} \overline{3} \mathrm{~s} \mathrm{C} 2 / \mathrm{m}$ & {$[27]$} \\
& $\mathrm{LiNi}_{0.5} \mathrm{Mn}_{1.5} \mathrm{O}_{4}$ & Cubic & $\mathrm{Fd} \overline{3} \mathrm{~m}$ & {$[28]$} \\
& & Cubic & $\mathrm{Fd} \overline{3} \mathrm{~m}$ & {$[18]$} \\
\hline
\end{tabular}

\section{- Layered Mn-based Oxides}

The main structural characteristics of layered oxides are: they adopt the $\alpha-\mathrm{NaFeO}_{2}$ structure as prototype, and possess cubic closed oxygen stacking, with metal ions occupied the $\mathrm{O}_{h}$ sites orderly [29].

\section{1. $\mathrm{LiMnO}_{2}$}

$\mathrm{LiMnO}_{2}$ has two competing ordered-rocksalt structures: orthorhombic $\mathrm{LiMnO}_{2}$ (o- $\mathrm{LiMnO}_{2}$, $\mathrm{Pmnm})$ and monoclinic $\mathrm{LiMnO}_{2}\left(\mathrm{~m}-\mathrm{LiMnO}_{2}, \mathrm{C} 2 / \mathrm{m}\right)$. O-LiMnO${ }_{2}$ has an ordered-rocksalt structure in which $\mathrm{MnO}_{6}$ and $\mathrm{LiO}_{6}$ octahedra are arranged in corrugated layers. $\mathrm{M}-\mathrm{LiMnO}_{2}$ has the cation ordering structure, in which Li ions are located in the layers of $\mathrm{O}_{\mathrm{h}}$ sites between $\mathrm{MnO}_{2}$ sheets [30].

If there is no JT effect, $\mathrm{LiMnO}_{2}$ is expected to be stable in the $\alpha-\mathrm{NaFeO}_{2}$ structure (space group $\mathrm{R} \overline{3} \mathrm{~m})$, like $\mathrm{LiCoO}_{2}$ [31]. When the cooperative JT distortion is introduced by $\mathrm{Mn}^{3+}\left(\mathrm{t}_{2 \mathrm{~g}}{ }^{3} \mathrm{eg}^{1}\right)$, the symmetry is reduced to monoclinic $(\mathrm{C} 2 / \mathrm{m})$. $\mathrm{M}-\mathrm{LiMnO}_{2}$ is unstable compared to o- $\mathrm{LiMnO}_{2}$, which is attributed to the collective distortion of octahedron in the corrugated-layer structure reducing the elastic energy and its $3 \mathrm{~d}$ spin ordering caused by the interaction between these moments [24,32].

$\mathrm{O}-\mathrm{LiMnO}_{2}$ is generally synthesized by high-temperature methods [33], while undoped $\mathrm{m}-\mathrm{LiMnO}_{2}$ has only been prepared by metastable synthesis routes such as ion-exchange from $\mathrm{NaMnO}_{2}$ and hydrothermal reaction [33]. However, doped $\mathrm{LiMnO}_{2}$ has been produced in the monoclinic phase, such as the $\mathrm{LiAl}_{x} \mathrm{Mn}_{1-\mathrm{x}} \mathrm{O}_{2}$, which is attributed to the non-JT effect of $\mathrm{Al}^{3+}$ [34].

The reasons of using different synthesis routs can be understood in terms of the relative sizes. The radius order of widely used cations in Li-ion batteries is: $\mathrm{Li}^{+}(0.76 \AA)>\mathrm{Ni}^{2+}(0.69 \AA)>\mathrm{Mn}^{3+}$ $(0.65 \AA)>\mathrm{Co}^{3+} \sim \mathrm{Ni}^{3+} \sim \mathrm{Mn}^{4+}(0.54 \AA)$. Larger difference between $\mathrm{Li}^{+}$and metal ions is beneficial to the formation of $2 \mathrm{D}$ structure [29], as a result, $\mathrm{LiCoO}_{2}$ and $\mathrm{LiNiO}_{2}$ enable strictly $2 \mathrm{D}$ layered oxides, while $\mathrm{Mn}^{3+}$ requires larger $\mathrm{Na}^{+}(1.02 \AA)$ to stabilize the layered structure, which then act as a precursor to obtain $\mathrm{LiMnO}_{2}$ by ion exchange [29].

2. $\mathrm{LiNi}_{-\mathrm{x}-\mathrm{y}} \mathrm{Co}_{\mathrm{x}} \mathrm{Mn}_{\mathrm{y}} \mathrm{O}_{2}$

Chemical substitution at the metal site of layered $\mathrm{LiMnO}_{2}$ has been intensively explored and several materials including two or three $3 \mathrm{~d}$ metals were produced synthetically considering cost reduction, safety and energy density, such as $\mathrm{LiNi}_{1 / 3} \mathrm{Co}_{1 / 3} \mathrm{Mn}_{1 / 3} \mathrm{O}_{2}, \mathrm{LiNi}_{0.5} \mathrm{Co}_{0.2} \mathrm{Mn}_{0.3} \mathrm{O}_{2}$, $\mathrm{LiNi}_{0.6} \mathrm{Co}_{0.2} \mathrm{Mn}_{0.3} \mathrm{O}_{2}, \mathrm{LiNi}_{0.8} \mathrm{Co}_{0.1} \mathrm{Mn}_{0.1} \mathrm{O}_{2}$, etc. They can be considered as solid solutions between $\mathrm{LiCoO}_{2}, \mathrm{LiNiO}_{2}$ and $\mathrm{LiMnO}_{2}$, isostructural with the pure $\mathrm{LiCoO}_{2}$ [26]. However, the distribution of the $\mathrm{Ni}, \mathrm{Mn}$, and Co metal cations is controversial: (1) considering the distribution as complete random in the established model [35]; (2) confirming the formation of $\mathrm{Ni}^{2+}$ and $\mathrm{Mn}^{4+}$ clusters through neutron pair distribution function (PDF) analysis, ${ }^{6} \mathrm{Li}$ magic angle spinning (MAS), nuclear magnetic resonance (NMR) spectroscopy, extended X-ray absorption fine structure (EXAFS) studies, and reverse Monte Carlo (RMC) calculations [36-38]; and (3) demonstrating long range ordering through calculations $[39,40]$. This may influence the oxidation state of $\mathrm{Ni}$ and $\mathrm{Mn}$ ions and electrochemical profile [37]. 
The oxidation states of the $\mathrm{Ni}, \mathrm{Co}$ and $\mathrm{Mn}$ ions in $\mathrm{LiNi}_{1-\mathrm{x}-\mathrm{y}} \mathrm{Co}_{\mathrm{x}} \mathrm{Mn}_{\mathrm{y}} \mathrm{O}_{2}$ are $+2,+3$ and +4 , respectively [6]. This can be explained by the different ionization energies of TM ions in oxide framework [2]. Take $\mathrm{Li}\left(\mathrm{Ni}_{0.5} \mathrm{Mn}_{0.5}\right) \mathrm{O}_{2}$ as an example. Since $\mathrm{Mn}^{3+}$ is more susceptible to be oxidized than $\mathrm{Ni}^{2+}$ (Figure 1), to meet the neutral requirements, the predicted valences of $\mathrm{Mn}$ and $\mathrm{Ni}$ are +4 and +2 , respectively [2].

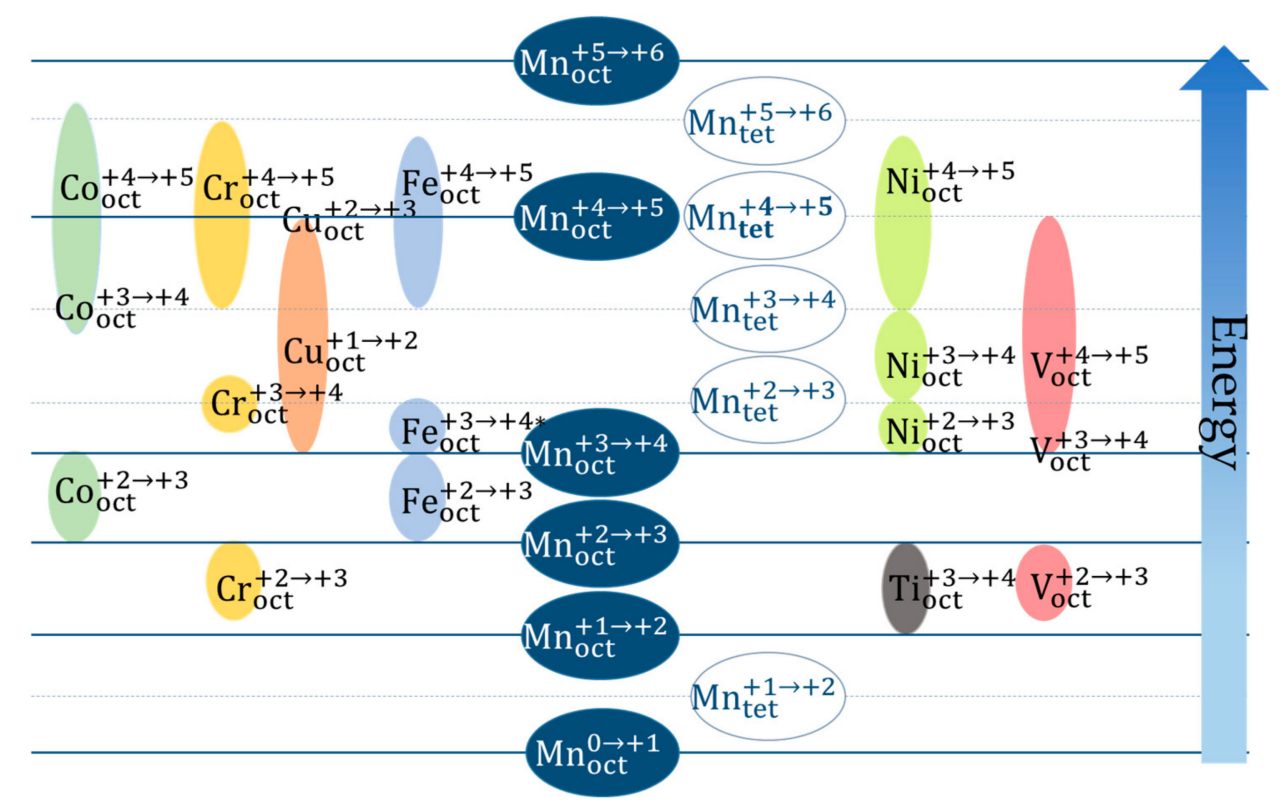

Figure 1. The ionization energies of $3 \mathrm{~d}$ ions at various valences in an oxide framework (Adapted with permission from [2], Copyright 2004, American Chemical Society).

\section{3. $\mathrm{Li}_{2} \mathrm{MnO}_{3}$}

$\mathrm{Li}_{2} \mathrm{MnO}_{3}$ exhibits an O3-type structure described in the monoclinic system (space group $\mathrm{C} 2 / \mathrm{m}$ ), and can be written in the normal layered stoichiometry as $\mathrm{Li}\left[\mathrm{Li}_{1 / 3} \mathrm{Mn}_{2 / 3}\right] \mathrm{O}_{2}$ [41]. The ordered distribution of the $\mathrm{Mn}^{4+} / \mathrm{Li}^{+}$cations in the mixed $\left[\mathrm{Li}_{1 / 3} \mathrm{Mn}_{2 / 3}\right] \mathrm{O}_{2}$ layer formed a honeycomb pattern in which lithium ions are surrounded by six metal ions [29].

$\mathrm{Li}_{2} \mathrm{MnO}_{3}$ was considered an electrochemically inactive material for a long time, since $\mathrm{Mn}^{4+}$ can hardly be oxidized further and the absence of free sites for extra lithium ions. However, it becomes electroactive when it is treated by acid [42] or charged to high potentials [27], which is attributed to the leaching of $\mathrm{Li}_{2} \mathrm{O}$ from the rock salt phase as well as the $\mathrm{H}^{+} / \mathrm{Li}^{+}$ion exchange. Considering $\mathrm{Li}_{2} \mathrm{MnO}_{3}$ is inactive in the range of $3 \sim 4 \mathrm{~V}$ and its (001) interlayer spacing is similar to the (003) spacing of layered $\mathrm{LiMO}_{2}(4.7 \AA)$ [20], it is possible to use $\mathrm{Li}_{2} \mathrm{MnO}_{3}$ as a structural stabilizer in layered $\mathrm{LiMO}_{2}$, leading to the formation of Li-rich layered oxide.

\section{Li-rich Layered Oxide}

Materials made of $\mathrm{Ni}$, Co and Mn with Li in excess (also termed as Li-Rich NCM) were firstly introduced by Thackeray et al. in 1993 [43]. These compounds are often written as three different notations: $x \mathrm{Li}\left[\mathrm{Li}_{1 / 3} \mathrm{Mn}_{2 / 3}\right] \mathrm{O}_{2} \cdot(1-\mathrm{x}) \mathrm{LiMO}_{2}, \mathrm{xLi}_{2} \mathrm{MnO}_{3} \cdot(1-\mathrm{x}) \mathrm{LiMO}_{2}$ or $\mathrm{Li}_{1+\mathrm{x}} \mathrm{M}_{1-\mathrm{x}} \mathrm{O}_{2}(\mathrm{M}=\mathrm{Mn}, \mathrm{Co}$, $\mathrm{Ni}$, etc.) [6].

The structure of Li-Rich NCM can be considered as a solid solution or a nanocomposite of layered $\mathrm{Li}_{2} \mathrm{MnO}_{3}$ and $\mathrm{LiMO}_{2}$. Perhaps the most wildly accepted statement [6] is the nanocomposite structure, in which the distribution of $\mathrm{Li}_{2} \mathrm{MnO}_{3}$-like and $\mathrm{LiMO}_{2}$-like nanodomains is short-range ordered, but not a completely solid solution. The peaks in Li-rich layered oxide XRD pattern can be indexed to the $\mathrm{R} \overline{3} \mathrm{~m}$ space group, with some exceptions in the $20^{\circ} \sim 25^{\circ}$ range attributed to $\mathrm{C} 2 / \mathrm{m}$ space group [29]. 
Synthesis routs will influence the structure and electrochemical performance of Li-rich layered oxide. For example, materials synthesized by hydrothermal assisted method are more uniform than those synthesized by co-precipitation and sol-gel methods, and hence demonstrate much better performances [44]. Xiang et al. claimed that preparation temperature significantly affect the oxidation process of cathodes during first charge [45].

- Spinel-type Mn-based Oxides:

\section{1. $\mathrm{LiMn}_{2} \mathrm{O}_{4}$}

The cubic spinel $\mathrm{LiMn}_{2} \mathrm{O}_{4}$ has a cation distribution of $(\mathrm{Li})_{8 \mathrm{a}}\left[\mathrm{Mn}^{3+} \mathrm{Mn}^{4+}\right]_{16 \mathrm{~d}} \mathrm{O}_{4}$. The $\mathrm{O}$ ions located at the 32e sites form a cubic closest packed (ccp) structure, and the $\mathrm{T}_{\mathrm{d}} 8 \mathrm{a}$ sites are occupied by Li ions and the $\mathrm{O}_{\mathrm{h}} 16 \mathrm{~d}$ sites are occupied by $\mathrm{Mn}$ ions [46]. $\mathrm{MnO}_{6}$ octahedrons are connected to each other through edge-sharing and hence form a three-dimensional network for lithium diffusion.

$\mathrm{LiMn}_{2} \mathrm{O}_{4}$ can be easily synthesized in air from variety precursors, reflecting the stability of spinel structure in $\mathrm{Li}-\mathrm{Mn}-\mathrm{O}$ system. If $\mathrm{Li}$ ions are extracted from the layered phase, the stable domain will fall into the spinel phase (Figure 2a).[47] Though spinel phase is metastable with respect to the formation of $\beta-\mathrm{MnO}_{2}$ (Figure $2 \mathrm{~b}$ ), this transformation requires the rearrangement of the oxygen layers, and thus spinel structure is stable under common conditions [12].

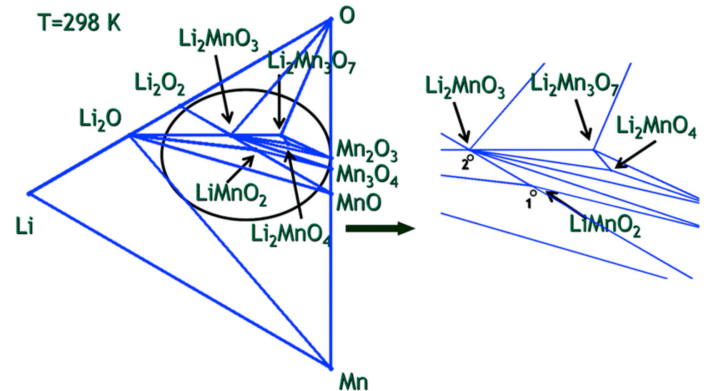

(a)

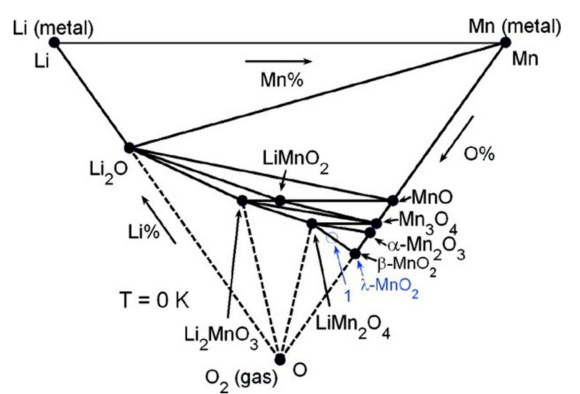

(b)

Figure 2. Calculated phase diagram of: Li-Mn-O system at room temperature (Reproduced from [47] with permission from the PCCP Owner Societies.) (a); and $\mathrm{Li}-\mathrm{Mn}-\mathrm{O}_{2}$ at $0 \mathrm{~K}$ (Reproduced with permission from [12], Copyright 2007, American Chemical Society) (b).

\section{2. $\mathrm{LiMn}_{2} \mathrm{O}_{4}$-based High-voltage Spinel Compounds}

For $\mathrm{Li}_{\mathrm{x}} \mathrm{M}_{\mathrm{y}} \mathrm{Mn}_{2-\mathrm{y}} \mathrm{O}_{4}(\mathrm{M}=\mathrm{Ni}, \mathrm{Co}, \mathrm{Fe}, \mathrm{Cr}, \mathrm{Mg}, \mathrm{Al}, \mathrm{Ti}, \mathrm{Cu}, \mathrm{Zn}$, etc.), the introduction of alien cations will not compromise the spinel structure. There are two different structures in $\mathrm{LiNi}_{0.5} \mathrm{Mn}_{1.5} \mathrm{O}_{4}$ related to the annealing history: disordered $\mathrm{Fd} \overline{3} \mathrm{~m}$ phase (Ni and Mn randomly occupy the $16 \mathrm{~d}$ sites) and ordered $\mathrm{P}_{3} 32$ phase (Ni and $\mathrm{Mn}$ is located in $4 \mathrm{a}$ and $12 \mathrm{~d}$ sites, respectively) [48]. Annealing at $700{ }^{\circ} \mathrm{C}$ makes the structure transformed from $\mathrm{Fd} \overline{3} \mathrm{~m}$ to $\mathrm{P}_{3} 32$, leading to the ordering of $\mathrm{Ni}$ and $\mathrm{Mn}$ ions [18].

\subsection{During Electrochemical Cycles}

\subsubsection{Involved Redox Couples and Voltage Profiles}

In the traditional cathodes, lattice oxygen mostly acts as a pillar to maintain the structure without participating redox processes. As lithium ions are extracted from the host material, charge neutrality requires changing the valence state of the TM or oxygen ions. The potential and possible involved redox couples depend on its electronic structure and chemistry, which can be predicted at a certain extent through theoretical computations. 
According to the Nernst equation, the voltage of a cell can be expressed as [49-51]:

$$
\text { Voltage }=-\frac{\mu_{\mathrm{Li}}^{\text {cathode }}-\mu_{\mathrm{Li}}^{\text {anode }}}{z e}
$$

where $e$ is the charge of an electron, $\mu_{\mathrm{Li}}^{\text {cathode }}$ and $\mu_{\mathrm{Li}}^{\text {anode }}$ is the chemical potentials per Li atom of in the cathode and anode respectively, $z$ is the valence of the ion, here $z$ equals to 1 .

In an intercalation system, since only the chemical potential and the amount of Li ions are changed during the charge/discharge processes, while the temperature and pressure remain constant, the Gibbs free energy can be written as:

$$
d G=\mu_{L i} d N_{L i} \text { (constant temperature and pressure) }
$$

where $\mu_{L i}$ is the chemical potential of $\mathrm{Li}, N_{L i}$ is the amount of $\mathrm{Li}$, and $G$ is the Gibbs free energy per $\mathrm{Li}_{\mathrm{x}} \mathrm{MA}$ formula unit (MA represents the host of electrode material).

For instance, consider the operating voltage of $\mathrm{Li}_{x} \mathrm{CoO}_{2}(0<\mathrm{x}<1)$ :

$$
\text { Voltage }=-\frac{\mu_{\mathrm{Li}}^{\mathrm{Li}_{\mathrm{C}} \mathrm{CoO}_{2}}-\mu_{\mathrm{Li}}^{\mathrm{anode}}}{e}=-\frac{\frac{d G}{d N_{L i}}-\mu_{\mathrm{Li}}^{\text {anode }}}{e} \approx-\frac{G\left(\mathrm{Li}_{\mathrm{y}} \mathrm{CoO}_{2}\right)-G\left(\mathrm{Li}_{x} \mathrm{CoO}_{2}\right)-\mu_{\mathrm{Li}}^{\text {anode }}}{e(y-x)}
$$

Li metal is usually used as the reference anode, and its chemical potential is $\mu_{\mathrm{Li}}^{\text {anode }}=-1.9 \mathrm{eV}$. Any changes in structure or chemistry of electrode during electrochemical cycles will alter its Li-chemical potential and Gibbs free energy, and hence the voltage. From this point of view, voltage measurements can provide direct thermodynamic information [49].

- Redox Couples Related to Transition Metal Cations

The $3 \mathrm{~d}$ transition metal oxides ( $3 \mathrm{~d}$ TM) are generally selected as the host owing to their appropriate energy to match the $\mathrm{O} 2 \mathrm{p}$ orbitals and relatively smaller molar mass. If the voltage values of several fictitious batteries combined with different TM oxides and metal $\mathrm{Li}$ are calculated with the hypothesis that all TM ions have the same valence, then one can obtain the voltage decreased with the order $\mathrm{Cu}$ $>\mathrm{Ni}>\mathrm{Co}>\mathrm{Fe}>\mathrm{Mn}>\mathrm{Cr}>\mathrm{V}>\mathrm{Ti}$ [7]. This is mainly caused by the decreased d-levels of the late TM oxides [51]. Moreover, in most lithium manganese oxides, lithium insertion into $\mathrm{O}_{\mathrm{h}}$ sites with simultaneous reduction of $\mathrm{Mn}(\mathrm{IV})$ to $\mathrm{Mn}(\mathrm{III})$ occurs at a voltage just above $3.0 \mathrm{~V}$ vs. Li. A higher voltage can be obtained if lithium is accommodated on $\mathrm{T}_{d}$ sites [52].

Several factors can influence the intercalation potential. Chen et al. [53] found that the intercalation potential is related to the electron affinity of transition metal cation, which is dominated by the combination of crystal-field splitting and the on-site d-d exchange interactions. Ceder et al. [51] claimed that the structural symmetry can affect the voltage. They believed that the transition metal is less important in determining the voltage than previously thought, and it should be considered much more as a means to stabilize the oxide structure since its d-bands are above the p-states of oxygen [51]. In addition, for polyanionic-type materials, the voltage can be tuned by $\mathrm{XO}_{4}$ groups (such as substitution of $\mathrm{PO}_{4}$ by $\mathrm{SO}_{4}$ ), which can be attributed to the weakened or strengthened covalency of TM-O bonds determined by the inductive effect of $\mathrm{XO}_{4}$ groups [54].

\section{- Redox Couples Related Oxygen Anions}

The fact that Li-Rich layered oxide can deliver excess capacity beyond the theoretical TM redox capacity at high voltage attracts great attention of researchers. This is attributed to the activation of oxide anions of the $\mathrm{Li}_{2} \mathrm{MnO}_{3}$-domain [20].

Rozier et al. [29] summarized the parameters influencing oxygen release from the behavior of $\mathrm{Li}_{2} \mathrm{Ni}_{0.5} \mathrm{Te}_{0.5} \mathrm{O}_{3}, \mathrm{Li}_{2} \mathrm{Ru}_{1-\mathrm{y}} \mathrm{Sn}_{\mathrm{y}} \mathrm{O}_{3}, \mathrm{Li}_{2} \mathrm{Fe}_{0.5} \mathrm{Sb}_{0.5} \mathrm{O}_{3}, \mathrm{Li}_{2} \mathrm{Fe}_{0.28} \mathrm{Te}_{0.5} \mathrm{O}_{3}$ and $\mathrm{Li}_{2} \mathrm{IrO}_{3}$ systems, and conclude that if the highest voltage is lower than the value of the $\mathrm{E}^{0}\left(\mathrm{O}^{2-} / \mathrm{O}^{2}\right)$ redox couple $(4.3 \mathrm{~V})$, oxygen evolution will not occur, consistent with the statement of Saubanere et al. [55] 
The mechanism of anionic redox is related to hybridization between the orbitals of TM ions and oxygen ions [56]. Seo et al. [57] proposed that the Li-O-Li configurations caused by the Li-excess environment around $\mathrm{O}$ contribute to the activation of anionic redox, since the extraction of labile electrons comes from unhybridized O $2 p$ states in Li-O-Li configurations. Saubanere et al. [55] suggested an M-driven reductive coupling mechanism, in which the M-O covalency determined the possibility of reversible $\mathrm{O}$ oxidation. The strong overlapping of the $\mathrm{M}(\mathrm{nd})-\mathrm{O}(\mathrm{sp})$ bands is explained as the driving force for the formation of $\left(\mathrm{O}^{2}\right)^{\mathrm{n}-}$ species. Luo et al. [58] demonstrated that $\mathrm{O}-\left(\mathrm{Mn}^{4+} / \mathrm{Li}^{+}\right)$ extract electrons more easier than $\mathrm{O}-\left(\mathrm{Ni}^{4+} / \mathrm{Co}^{4+}\right)$, owing to its more ionic and localized $\mathrm{O} 2 \mathrm{p}$ orbitals interactions. Saubanere et al. [55] claimed that the stronger $3 \mathrm{~d}$ TM-O bonds comparing to $4 \mathrm{~d} / 5 \mathrm{~d}$ TM-O bonds and no empty $\mathrm{MO}^{*}$-orbitals closing to the top of O-band make $\mathrm{O}_{2}$ evolution easier in $3 \mathrm{~d}$ TM system.

- Voltage Profiles

While the involved redox couples mirror the voltage values, the shape of voltage curves is determined by the electrochemical process. Voltage profiles can be speculated from Equation (5), as shown in Figure 3 [49]. In addition, if an electrode material forms solid solution in charge/discharge processes, its voltage profile exhibits a smooth sloping as occurring in $\mathrm{LiNi}_{1 / 3} \mathrm{Co}_{1 / 3} \mathrm{Mn}_{1 / 3} \mathrm{O}_{2}$, while, if a first-order phase transformation takes place, the profile will show a plateau as occurring in $\mathrm{LiMn}_{2} \mathrm{O}_{4}$.

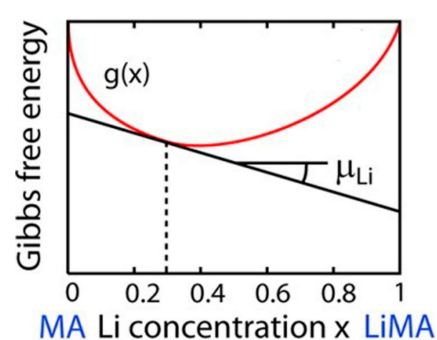

(a)

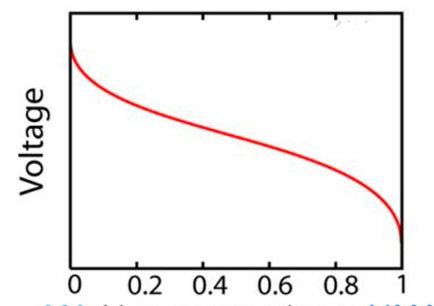

MA Li concentration $x$ LiMA

(b)

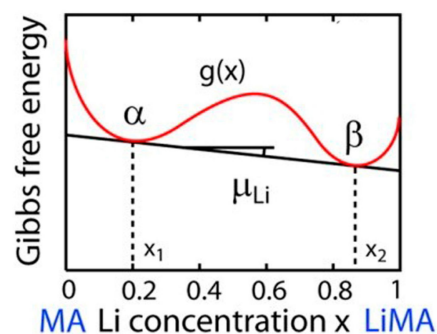

(c)

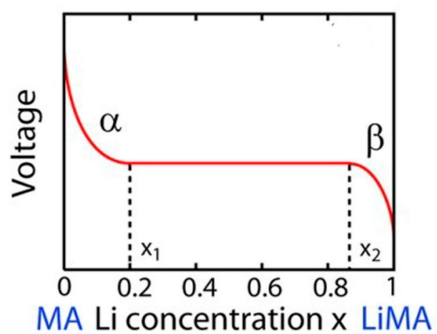

(d)

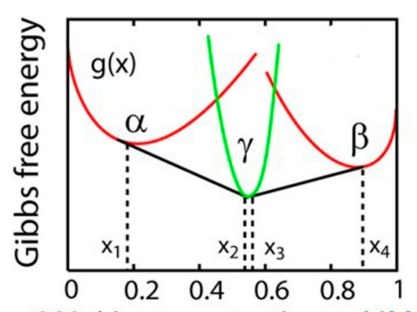

MA Li concentration $x$ LiMA

(e)

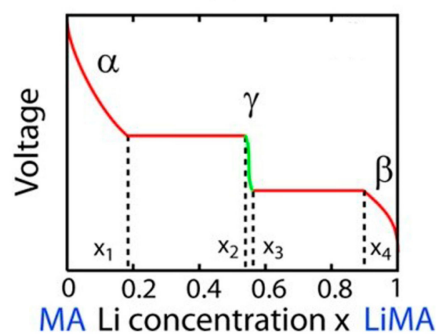

(f)

Figure 3. (a-f) The relationship between voltage curves and the slope of the free energy (Reproduced with permission from [49], Copyright 2013, American Chemical Society).

\subsubsection{Phase Changes during Cycling}

Phase changes during cycling, especially long-term cycling, affect the performance of cathode material obviously. The attempt of the ideal host material, which can maintain its structure during the intercalation/deintercalation of lithium ions, sometimes fails, due to the varied chemical environment during electrochemical processes. However, the phase changes may be kinetically controlled, and hence some materials are relatively stable during cycling. The phase behavior of different materials varied widely, which will be discussed in this part.

- Layered $\mathrm{LiMnO}_{2}$

The layered-to-spinel transformation is thermodynamically favored in both $\mathrm{Li}_{x} \mathrm{CoO}_{2}$ and $\mathrm{Li}_{x} \mathrm{MnO}_{2}$, however, $\mathrm{LiCoO}_{2}$ does not undergo such a conversion. This suggests the transformation is 
related to kinetic factors [12]. When layered $\mathrm{Li}_{0.5} \mathrm{MnO}_{2}$ convert to spinel, one-fourth $\mathrm{Mn}$ ions move into the lithium layer corresponding to the $16 \mathrm{~d}$ sites of spinel, while lithium ions migrate to $T_{d}$ sites corresponding to the 8a positions of spinel.

Reed et al. [59] claimed a two-stage mechanism for the layered-to-spinel conversion. In the first stage, a fraction of Mn ions rapidly migrate to adjacent $T_{d}$ sites in the lithium layer owing to the low activation barrier $(0.2 \mathrm{eV})$ and the disproportionation reaction of $\mathrm{Mn}^{3+}$, accompanied by roughly an equal amount of lithium ions entering octahedral vacancies left by $\mathrm{Mn}$, and hence forming "Li-Mn dumbbells". In the second stage, the tetrahedral Mn ions and octahedral Li ions rearrange to form the final spinel phase. Vitins et al. [52] also suggested that the high mobility of $\mathrm{Mn}^{2+}$ leads to the random distribution of Mn cations, which can easily relax to the Mn distribution characteristic of spinels.

- $\mathrm{Li}\left(\mathrm{Ni}_{1-\mathrm{x}-\mathrm{y}} \mathrm{Co}_{\mathrm{x}} \mathrm{Mn}_{\mathrm{y}}\right) \mathrm{O}_{2}$ :

In $\mathrm{Li}\left(\mathrm{Ni}_{1-x-y} \mathrm{Co}_{x} \mathrm{Mn}_{y}\right) \mathrm{O}_{2}$, with the increase in $\mathrm{Mn}$ content and decrease in Ni content, the reversible capacity decreased, whereas the structural stability improved (Figure 4) [5,6,60].

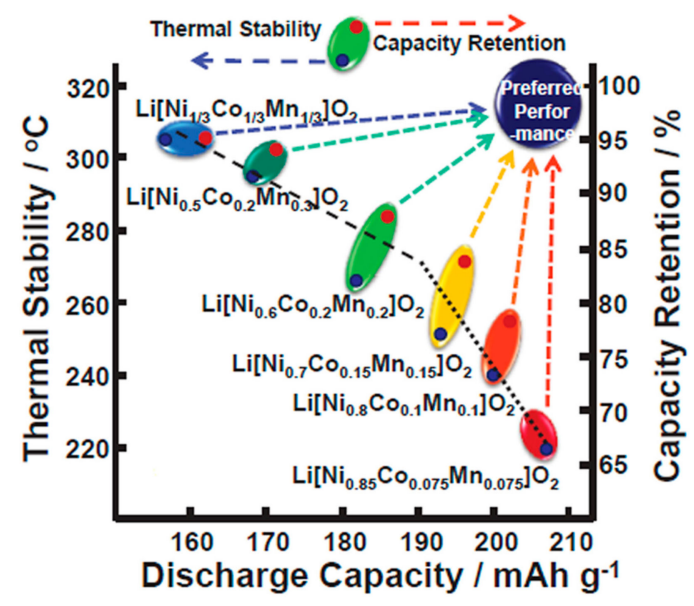

Figure 4. The relationship between discharge capacity, thermal stability and capacity retention of $\mathrm{Li}\left(\mathrm{Ni}_{1-\mathrm{x}-\mathrm{y}} \mathrm{Co}_{\mathrm{x}} \mathrm{Mn}_{\mathrm{y}}\right) \mathrm{O}_{2}$ (Reproduced from [5], Copyright 2013, with permission from Elsevier).

This might be attributed to the following reasons: (1) Ni ions act as the main active redox species $\left(\mathrm{Ni}^{2+} /{ }^{4+}\right)$ but have poor thermal stability. The highly reactive $\mathrm{Ni}^{4+}$ can accelerate the side reactions with electrolyte, which cause a thick insulating solid-state electrolyte interface layer [61]. The migration of $\mathrm{Ni}^{2+}$ destroys active lithium sites, leading to a gradual capacity decline[61]; (2) $\mathrm{Mn}^{4+}$ ions provided significant structural stability attributed to its octahedral affinity and non-JT effect [3]; (3) Co offers increased electrical conductivity and lowered the cation mixing between $\mathrm{Li}$ and $\mathrm{Ni}$, resulting in an excellent rate capability $[5,62,63]$.

However, slight phase changes can still occur in $\mathrm{Li}\left(\mathrm{Ni}_{1 / 3} \mathrm{Co}_{1 / 3} \mathrm{Mn}_{1 / 3}\right) \mathrm{O}_{2}$, as demonstrated by Yin et al. [26] who claimed that the phase of $\mathrm{Li}_{\mathrm{x}}\left(\mathrm{Ni}_{1 / 3} \mathrm{Co}_{1 / 3} \mathrm{Mn}_{1 / 3}\right) \mathrm{O}_{2}$ changes from O3 phase $(\mathrm{R} \overline{\mathrm{m}} \mathrm{m})$ to the $\mathrm{O} 1(\mathrm{P} \overline{\mathrm{z}} \mathrm{m} 1)$ when charged to $\mathrm{x}=0.3$, as a result of minimizing the van der Waals gap interactions. When $x>0.3$, small volume variation $(1 \%)$ is observed and the structure is maintained, while, if $x<0.3$, re-intercalation of lithium was relatively irreversible in the subsequent cycle accompanied by a large volume change $(7.2 \%)$.

- Li-rich Oxides:

In the initial charge, Li-rich compounds present a staircase charge profile and an S-shape discharge profile. Afterwards, the S-shape voltage profile is preserved on subsequent charge/discharge cycles [29]. The initial charge curve consists of two regions: a sloping before $4.4 \mathrm{~V}$ and a plateau after 
4.4 V. During the first part, $\mathrm{Li}$ is extracted with the oxidation of the TM ions. The second part consists of Li being removed accompanied by the reversible or irreversible oxidation of oxide ions [6].

In the first cycle, several phase changes occurred: (1) oxygen is evolved from the surface of the material [64], whereas the bulk oxygen is oxidized without oxygen loss [65]; (2) irreversible loss of $\mathrm{O}_{2}$ results in O deficient layered materials [65,66]; and (3) the changed oxygen and charge environment induce the transition metal ions' diffusion from surface to bulk, and hence result in a denser lattice [64]. Moreover, metal ions tend to occupy the neighboring $\mathrm{O}_{\mathrm{h}}$ sites left by lithium ions as well as rearrange in the metal plane [67-70]. Though the exact structure of the defect phase is not completely clear, it is generally considered as a spinel-like phase $[6,13,14]$.

Due to the severe phase changes in the first cycle, it can be anticipated that the realized reversible capacity during subsequent cycles is closely connected to the behavior in the first cycle. It has been reported that the reversible capacity is proportional to the length of the plateau region, which could be changed by doping [71]. Manthiram et al. [71] systematically studied how the doping ions affects the plateau length, and demonstrated that the plateau region decreases with the order $\mathrm{Co}>$ pristine $>\mathrm{Fe}>\mathrm{Al}>\mathrm{Cr}>\mathrm{Ga}$, attributed to the decreased metal-oxygen covalence. In addition, Lee et al. [72] suggested that the length of plateau region during the first charge significantly affect the voltage decay of Li-rich layered oxides.

It should be mentioned that the origin of plateau region is the phase conversion during cycling, and thus the formation of spinel-like phase leads to a series of phenomenon, such as voltage hysteresis, capacity and voltage fading. The voltage hysteresis, closely related to the $\mathrm{Li}_{2} \mathrm{MnO}_{3}$ component [73], is caused by the migration of TM ions into $\mathrm{Li}^{+}$layers [74,75]. Since the movement is some extent irreversible, the inactive metal ions in Li-layer result in a capacity fading [74]. The phase transformation and the microstrain within particles $[29,76]$ also attributed to the capacity decay. Though the mechanism of voltage fade is still controversial, the main statements are [6]: (1) Li was trapped in the dumbbell structures accompanied by the migration of TM ions; and (2) TM ions are trapped in Li-layer or tetrahedral sites.

Extensive work has been done to improve the performance of Li-rich layered oxides from these aspects: (1) inhibit the growth of the spinel-like phase [77,78]; (2) protect electrode from side reactions with the electrolyte [79]; (3) form composite materials [80,81]; and (4) reduce the oxygen partial pressure on the surface of material [82].

- $\mathrm{LiMn}_{2} \mathrm{O}_{4}$

In theory, $\mathrm{LiMn}_{2} \mathrm{O}_{4}$ can either be discharged or charged initially, and then cycled over a composition range of $0 \leq x \leq 2$ in $\mathrm{Li}_{x} \mathrm{Mn}_{2} \mathrm{O}_{4}$. When $\mathrm{Li}_{x} \mathrm{Mn}_{2} \mathrm{O}_{4}$ is discharged in the range of $1<\mathrm{x}<2$, lithium ions are inserted to empty $\mathrm{O}_{\mathrm{h}} 16 \mathrm{c}$ sites, accompanied by a large anisotropic volume change $(6.5 \%)$ caused by the formation of tetragonally distorted $\mathrm{Li}_{2} \mathrm{Mn}_{2} \mathrm{O}_{4}[27,28]$. As a result, in practice, the cycle is generally limited in $0<x<1$, in which lithium ions are intercalated/deintercalated from the $T_{d}$ $8 \mathrm{a}$ sites, and the cubic structure is maintained. In fact, $\mathrm{Li}_{x} \mathrm{Mn}_{2} \mathrm{O}_{4}(0<\mathrm{x}<1)$ is not thermodynamically stable at low lithium content. The excellent structural stability may be explained as follows: (1) when $\mathrm{x} \approx 0, \mathrm{Mn}$ ions are primarily in +4 valence state with low mobility; and (2) when $\mathrm{x} \approx 1$, there are insufficient Li vacancies for Mn rearrangement [2].

However, gradual capacity fading was still observed, especially at elevated temperature $\left(>55^{\circ} \mathrm{C}\right)$. This is attributed to the following reasons: (1) The dissolution of $\mathrm{Mn}^{2+}$, associated with $\mathrm{Mn}^{3+}$ disproportionation (Equation (6)) in the presence of acidic components of the $\mathrm{LiPF}_{6}$ /organic carbonate electrolyte solutions, destroys the spinel structure and the leaving $\mathrm{Mn}^{4+}$ which cannot be oxidized further $[27,83]$; (2) The two-phase structure in the high voltage region easily transformed to a one phase structure (e.g., a lithium-rich structure) accompanied by the dissolution of Mn and the loss of oxygen [83,84].

$$
2 \mathrm{Mn}^{3+}(\text { solid }) \rightarrow \mathrm{Mn}^{4+}(\text { solid })+\mathrm{Mn}^{2+}(\text { solution })
$$


- $\mathrm{LiMn}_{2} \mathrm{O}_{4}$-based High-voltage Spinel Compounds

To avoid the Jahn-Teller effect caused by $\mathrm{Mn}^{3+}$ and Mn dissolution, the oxidation state of $\mathrm{Mn}$ is increased by substituting $\mathrm{Mn}$ with lower valence metal ions, causing a series of compounds with a general formula of $\mathrm{LiM}_{\mathrm{x}} \mathrm{Mn}_{2-\mathrm{x}} \mathrm{O}_{4}(\mathrm{M}=\mathrm{Ni}, \mathrm{Co}, \mathrm{Fe}, \mathrm{Cr}, \mathrm{Mg}, \mathrm{Al}, \mathrm{Ti}, \mathrm{Cu}, \mathrm{Zn}$, etc.). Those compounds can deliver capacities at around $5 \mathrm{~V}$, and thus the corrosion reaction between the cathode surface and electrolyte is one of the main problems [18]. In $\mathrm{LiNi}_{0.5} \mathrm{Mn}_{1.5} \mathrm{O}_{4}$, the amounts of dissolved $\mathrm{Mn}$ and $\mathrm{Ni}$ increase with state of charge, temperature, and storage time [85]. Moreover, the phase change behavior of the ordered phase is different from that of disordered one, though they all go through three stages [86]. In the ordered phase, the change occurs earlier during discharge since a larger parameter variation [86].

\section{Kinetics}

Diffusion properties of electrode affect some of the key properties in Li-ion batteries, such as rate performance, cycling stability and practical capacity $[87,88]$. In the following part, the electrical and ionic conductivity will be discussed.

\subsection{Electrical Conductivity}

The intrinsic electrical conductivity originates from the electronic structure of the electrode materials, which can be derived via quantum mechanical calculation. From a quantum mechanics point of view, only electrons nearing the Fermi level can be involved in the electron movement, which is more meaningful than the classical free electron gas model [87]. Therefore, it is necessary to discuss the electronic structures of cathode materials.

In most Mn-based intercalation cathodes, the TM-O covalent interaction arises mainly from the $\mathrm{Mn}-3 \mathrm{~d}$ and O-2p hybridization. However, the type of $\mathrm{Li}-\mathrm{O}$ bond is controversial: some researchers believed that $\mathrm{Li}^{+}$is fully ionized [89], while others claimed a weak covalent interaction arising from the Li-2p/O-2p hybridization [90]. In the process of lithium insertion, each lithium loses almost one electron, and most of these electrons transfer to surrounding O-2p orbitals [90] or the Mn-3d band [91]. When lithium atoms are extracted from cathodes, the electrons are removed from the TM orbits in most cases. For example, in $\mathrm{LiCr}_{\mathrm{x}} \mathrm{Mn}_{2-\mathrm{x}} \mathrm{O}_{4}$, the electrons are first removed from $\mathrm{Mn} \mathrm{e}_{\mathrm{g}}$, followed by $\mathrm{Crt}_{2 \mathrm{~g}}$ orbital [91]. The electrical conductivity of a cathode material can be determined, in some degree, by its electron densities at the Fermi level, which can be obtained from [87]:

$$
\begin{gathered}
\sigma=\frac{1}{3} e^{2} v_{F}^{2} \tau N\left(E_{F}\right) \\
N\left(E_{F}\right)=2\left(\frac{k_{B} T}{2 \pi \hbar^{2}}\right)^{\frac{3}{2}}\left(m_{e} m_{h}\right)^{\frac{3}{4}} \exp \left(-\frac{E_{g}}{2 k_{B} T}\right)
\end{gathered}
$$

where $\sigma$ is the electrical conductivity, $\mathrm{S} \mathrm{cm}^{-1}$; $e$ is the charge of an electron, $1.602 \times 10^{-19} \mathrm{C} ; N\left(E_{F}\right)$ is the number of available electron, $\mathrm{mol} \mathrm{eV}^{-1} ; v_{F}$ is the Fermi velocity, $\mathrm{cm} \mathrm{s}^{-1} ; \tau$ is the relaxation time, $\mathrm{s}$; $k_{B}$ is the Boltzmann constant, $1.38054 \times 10^{-23} \mathrm{~J} \mathrm{~K}^{-1} ; T$ is the temperature, $\mathrm{K} ; \hbar$ is the reduced Planck's constant, $1.055 \times 10^{-34} \mathrm{~J} \mathrm{~s} ; m_{e}$ is the effective mass of an electron, $\mathrm{kg} ; m_{h}$ is the effective mass of holes, $\mathrm{kg}$; and $E_{g}$ is the band gap, $\mathrm{eV}$.

Take $\mathrm{LiMn}_{2} \mathrm{O}_{4}$ as an example. The Fermi energy level $\left(\mathrm{E}_{\mathrm{f}}\right)$ of $\mathrm{LiMn}_{2} \mathrm{O}_{4}$ is located in the $\mathrm{Mn}$ $t_{2 g}$ band and the Mn e $e_{g}$ band lies above it. There is an energy gap of about $2 \mathrm{eV}$ between the O-2p and the Mn-3d band, reflecting a semiconductor feature [90,92]. When doped with $\mathrm{Cu}$, the electrical conductivity increased owing to the contribution of $\mathrm{Cu} \mathrm{e}_{\mathrm{g}}$ holes to charge transport $[93,94]$. The band gaps and electrical conductivities at room temperature of several cathodes are summarized in Table 4 . However, there are no viable theories to quantitatively describe the conduction properties using band gap analysis yet [87]. 
Table 4. Electrical conductivities of several cathodes at room temperature.

\begin{tabular}{cccc}
\hline Cathode Material & Band Gap (eV) & Electrical Conductivity $\left(\mathbf{S ~ c m}^{\mathbf{- 1}}\right)$ & References \\
\hline orthorhombic-LiMnO & $\sim 1.9$ & - & {$[95]$} \\
$\mathrm{LiCoO}_{2}$ & $0.5 \sim 2.7$ & $\sim 10^{-4}$ & {$[87]$} \\
$\mathrm{Li}\left(\mathrm{Ni}_{1 / 3} \mathrm{Co}_{1 / 3} \mathrm{Mn}_{1 / 3}\right) \mathrm{O}_{2}$ & - & $5.2 \times 10^{-8}$ & {$[5]$} \\
$\mathrm{Li}\left(\mathrm{Ni}_{0.5} \mathrm{Co}_{0.2} \mathrm{Mn}_{0.3}\right) \mathrm{O}_{2}$ & - & $4.9 \times 10^{-7}$ & {$[5]$} \\
$\mathrm{Li}\left(\mathrm{Ni}_{0.6} \mathrm{Co}_{0.2} \mathrm{Mn}_{0.2}\right) \mathrm{O}_{2}$ & - & $1.6 \times 10^{-6}$ & {$[5]$} \\
$\mathrm{Li}\left(\mathrm{Ni}_{0.8} \mathrm{Co}_{0.1} \mathrm{Mn}_{0.1}\right) \mathrm{O}_{2}$ & - & $1.7 \times 10^{-5}$ & {$[5]$} \\
$\mathrm{LiMn}_{2} \mathrm{O}_{4}$ & $0.28 \sim 2.2$ & $\sim 10^{-6}$ & {$[87]$} \\
$\mathrm{LiMnPO}_{4}$ & $3.8 \sim 4.0$ & $\sim 10^{-14}$ & {$[96]$} \\
\hline
\end{tabular}

\subsection{Ion Diffusion}

Comparing to the ionic conduction, electrical conduction is not a dominant factor for intercalation cathodes in most cases $[49,87]$. Diffusion processes of Li-ion include several aspects such as grain boundary diffusion, anode and electrolyte resistance as well as interfacial diffusion. Here, we only focus on the lithium ion conductivity in Mn-based intercalation cathodes. In addition, the migration of cations will also be discussed.

\subsubsection{Ion Transport Mechanisms}

There are two concepts in describing the motion of Li-ions: ion diffusion coefficient $D_{i}$ (or diffusivity) and ionic conductivity $\sigma_{i}$.

The diffusion coefficient of ions $D_{i}\left(\mathrm{~cm}^{2} \mathrm{~s}^{-1}\right)$ represents the ease of ions passing through Media under a concentration gradient, the definition of which is [49]:

$$
-j_{i}=D_{i} \nabla c_{i}
$$

where $j_{i}$ is the ionic flux, $\mathrm{mol} \mathrm{cm} \mathrm{c}^{-2} \mathrm{~s}^{-1}$; and $\nabla c_{i}$ is the concentration gradient.

The ionic conductivity $\sigma_{i}\left(\mathrm{~s} \mathrm{~cm}^{-1}\right)$ represents the motion of $\mathrm{Li}^{+}$under external electrical potential, the definition of which is [87]:

$$
\sigma_{i}=j / \xi
$$

where $j$ is the current density, $\mathrm{A} \mathrm{cm}^{-2}$; and $\xi$ is the electric field, $\mathrm{V} \mathrm{cm}^{-1}$.

Both diffusivity and ionic conductivity are used to describe the motion of $\mathrm{Li}^{+}$. Generally, diffusion coefficient in electrode materials is hard to measure experimentally, whereas ionic conductivity is easier to measure, and thus the former could be deduced from measuring ionic conductivity [87]:

$$
\sigma_{i}=\frac{q_{i}^{2} c_{i}}{k_{B} T} D_{i}
$$

where $\sigma_{i}$ is the ionic conductivity, $\mathrm{S} \mathrm{cm}^{-1} ; q_{i}$ is numbers of holes, $\mathrm{cm}^{-3} ; c_{i}$ is concentration of $i, \mathrm{~mol} \mathrm{~cm}^{3}$; $k_{B}$ is the Boltzmann constant, $1.38054 \times 10^{-23} \mathrm{~J} \mathrm{~K}^{-1}$; $T$ is the temperature, $\mathrm{K}$; and $D_{i}$ is the diffusivity of ions, $\mathrm{cm}^{2} \mathrm{~s}^{-1}$.

The generic diffusion mechanism for solid phase is a good start to understand the diffusion behavior in electrodes. Several diffusion mechanisms in solids are listed in Table 5 [97].

For intercalation cathode, Li-ions diffuse mainly by an interstitial or vacancy mechanism [87], the jump diffusion coefficient of which could be expressed as [49,87,98]:

$$
\begin{gathered}
D_{i}=a_{l}^{2} \Gamma \\
\Gamma=v^{0} \exp \left(-\frac{\Delta G}{k_{B} T}\right)
\end{gathered}
$$


where $a_{l}$ is the jump length, $\Gamma$ is the hopping rate (or frequency), $v^{0}$ is an effective vibrational frequency (or attempt frequency) and $\Delta G$ is the activation barrier for the hop which can be determined by the nudged elastic band method.

From Equation (12), the diffusion coefficient is determined by jump rates and jump distance [97,99], which is affected by bonding potential and defects. As a result, it is important to consider crystal structure and surrounding potential carefully [87], which will be discussed in the next part.

Table 5. Diffusion mechanisms in solids [97].

\begin{tabular}{|c|c|c|}
\hline Mechanisms & Descriptions & Examples \\
\hline Direct interstitial & $\begin{array}{l}\text { An interstitial solid solution can diffuse by jumping } \\
\text { from one interstitial site to one of its } \\
\text { neighboring sites. }\end{array}$ & $\begin{array}{l}\text { The diffusion of small foreign } \\
\text { atoms such as } \mathrm{H}, \mathrm{C}, \mathrm{N} \text {, and } \mathrm{O} \\
\text { in metals. }\end{array}$ \\
\hline Collective & $\begin{array}{l}\text { Simultaneous motion of several atoms in a chain-like } \\
\text { or caterpillar-like fashion. }\end{array}$ & $\begin{array}{l}\text { The motion of alkali ions in } \\
\text { ion-conducting oxide glasses. }\end{array}$ \\
\hline Vacancy & $\begin{array}{l}\text { An atom jumps into a neighboring vacancy, making a } \\
\text { series of exchanges with vacancies. }\end{array}$ & $\begin{array}{l}\text { The diffusion of substitutional } \\
\text { solutes and of matrix atoms } \\
\text { in metals. }\end{array}$ \\
\hline Divacancy & $\begin{array}{l}\text { When a binding energy exists, which tends to create } \\
\text { agglomerates of vacancies, diffusion occur via } \\
\text { aggregates of vacancies. }\end{array}$ & The diffusion of $\mathrm{Li}^{+}$in $\mathrm{LiCoO}_{2}$. \\
\hline Indirect interstitial & $\begin{array}{l}\text { A lattice atom is knocked out by a neighboring } \\
\text { interstitial atom from its lattice positions under } \\
\text { irradiating/ heating, and then deposited in the lattice } \\
\text { as a self-interstitial. }\end{array}$ & Radiation-induced diffusion. \\
\hline $\begin{array}{l}\text { Interstitial-substitutional } \\
\text { exchange }\end{array}$ & $\begin{array}{l}\text { Some solute atoms may be dissolved on both } \\
\text { interstitial and substitutional sites of a host crystal. }\end{array}$ & $\begin{array}{l}\text { The diffusion of } \mathrm{Au}, \mathrm{Pt}, \mathrm{Zn} \\
\text { in silicon. }\end{array}$ \\
\hline
\end{tabular}

\subsection{2. $\mathrm{Li}^{+}$Diffusion in Different Structures}

The ion diffusion topology of lithium cathode can be divided in terms of the dimensionality, for example, 1D in olivine $\mathrm{LiFePO}_{4}$ (Figure 5c), 2D in layered $\mathrm{LiCoO}_{2}$ (Figure 5a) and 3D in spinel $\mathrm{LiMn}_{2} \mathrm{O}_{4}$ (Figure $5 \mathrm{~b}$ ). The dimensionality of diffusion has a considerable impact on macroscopic conductivity in a material [100].

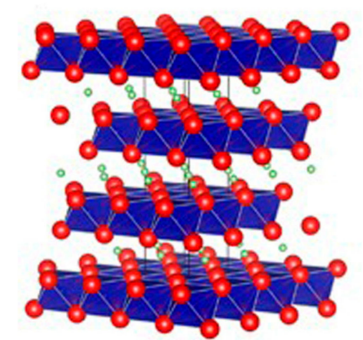

(a)

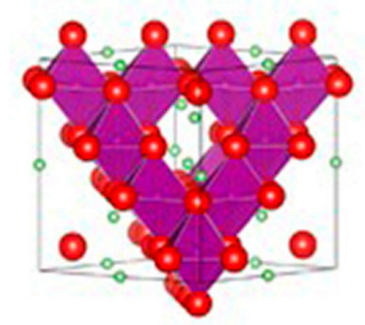

(b)

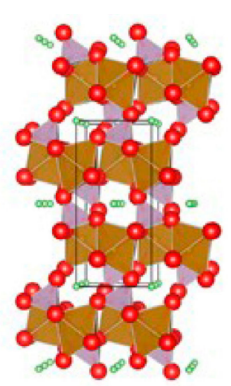

(c)

Figure 5. Crystal structure of: layered $\mathrm{LiCoO}_{2}$ (a); spinel $\mathrm{LiMn}_{2} \mathrm{O}_{4}$ (b); and olivine $\mathrm{LiFePO}_{4}$ (c) (Reproduced with permission from [100]).

\section{- 1D Olivine:}

The planes of Li chains in the olivine structure may form ion conducting 2D layers, analogous to layered $\mathrm{LiMO}_{2}(\mathrm{M}=\mathrm{Co}, \mathrm{Mn}, \mathrm{Ni}$, etc.). However, the $\mathrm{Li}$ ions within the chains are only $3.0 \AA$ apart, whereas the distances between the chains are at least $4.7 \AA$. The large interchain distances, as well as the complex energy landscape between chains, make interchain Li hopping difficult and favor the 
adoption of [010] $]_{\text {Pnma }}$ axis as 1D tunnels [99]. Islam et al. [99] suggested a nonlinear, curved trajectory between adjacent $\mathrm{Li}$ sites. The diffusion coefficient $\mathrm{D}$ is $10^{-13} \sim 10^{-12} \mathrm{~cm}^{2} \mathrm{~s}^{-1}$ for $\mathrm{LiFe}_{1-\mathrm{x}} \mathrm{Mn}_{\mathrm{x}} \mathrm{PO}_{4}$ [101].

- 2D Layered $\mathrm{LiMO}_{2}$ :

In layered transition metal oxides, such as $\mathrm{Li}_{\mathrm{x}}\left(\mathrm{Ni}_{1 / 3} \mathrm{Co}_{1 / 3} \mathrm{Mn}_{1 / 3}\right) \mathrm{O}_{2}$ and $\mathrm{LiMnO}_{2}$, the least hindered hop path between neighboring $\mathrm{O}_{h}$ sites is along a curved path that passes through an adjacent $T_{d}$ site (o-t-o migration), since the direct migration through the $\mathrm{O}-\mathrm{O}$ edge shared by the $\mathrm{O}_{h}$ sites is too high in energy (Figure 6a) $[49,102]$. The energy of an intermediate $T_{d}$ site is determined by its coordinated extent with neighboring cations. In the layered host, the intermediate $T_{d}$ site shares a face with an octahedron which contains a transition metal, resulting in a strong repulsion [49]. However, when hopping into a divacancy, the repulsion is absent and hence the migration barrier is smaller. Therefore, lithium diffusion is predominantly mediated by a divacancy mechanism in layered oxides [49]. Since the diffusion channel passes through one adjacent TM ion, it is generally noted as a 1-TM channel. Moreover, all lithium sites in stoichiometric layered materials are equivalent, and thus form a 2D network. The diffusion coefficient is $10^{-13} \sim 10^{-7} \mathrm{~cm}^{2} \mathrm{~s}^{-1}$ for $\mathrm{LixCoO}_{2}$ [99].

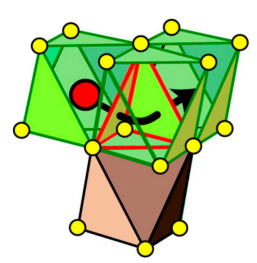

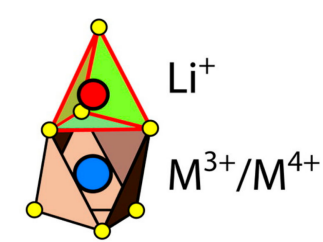

(a)

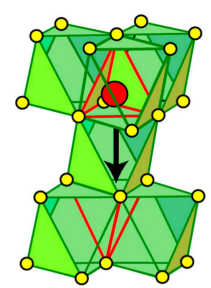

(b)

Figure 6. Illustrations of Li hoping route in: layered oxides (a); and spinel oxides (b) (Reproduced with permission from [49], Copyright 2013, American Chemical Society).

The two dominant factors affecting diffusion coefficient are: the size of $\mathrm{T}_{\mathrm{d}}$ site determined by the c-lattice parameter, and the electrostatic repulsion between $\mathrm{Li}$ and neighboring transition metal ions [103]. The chemical diffusion coefficient has a strong concentration dependency, which decreases as $\mathrm{Li}$ ions are removed, owing to the increase in effective valence of TM ions and the contraction of the lattice parameter $[49,98]$. For example, the activation barrier in $\mathrm{Li}_{x} \mathrm{CoO}_{2}$ increases by more than 300 $\mathrm{meV}$ as $\mathrm{x}$ is reduced from 1 to 0 [98]. Other factors such as cation doping can be interpreted in terms of the size and electrostatic effect. Electronic effects can also affect the migration barriers when JT cations are involved.

Other factors arise from the wide compositions and complex structure in layered- $\mathrm{LiMO}_{2}(\mathrm{M}=\mathrm{Ni}$, $\mathrm{Co}, \mathrm{Mn}, \mathrm{Al}$, etc.) system. In alloyed layered compounds such as $\mathrm{Li}_{\mathrm{x}}\left(\mathrm{Ni}_{1-\mathrm{y}-\mathrm{z}} \mathrm{Co}_{\mathrm{y}} \mathrm{Mn}_{\mathrm{z}}\right) \mathrm{O}_{2}$, additional complexity is introduced by the different electron affinities of TM ions. For instance, in $\mathrm{Li}\left(\mathrm{Ni}_{0.5} \mathrm{Mn}_{0.5}\right)$ $\mathrm{O}_{2}$, in which $\mathrm{Ni}$ and $\mathrm{Mn}$ are in +2 and +4 valence state, respectively, the diffusion barrier passed by $\mathrm{Ni}^{2+}$ ions is lower than that passed by $\mathrm{Mn}^{4+}$ ions. Venkatraman et al. [104] demonstrated that cation disorder in Ni-rich $\mathrm{LiNi}_{1-x-y} \mathrm{Co}_{x} \mathrm{Mn}_{y} \mathrm{O}_{2}$ materials significantly decreases the lithium extraction rate through chemical extraction experiment, consistent with the study of Urban et al.[105] It can be interpreted by the smaller slab distances. However, the disordered materials with excess lithium are reported to possess facile lithium diffusion, which can be attributed to the formation of 0-TM channels in the presence of excess lithium environment [104].

- 3D Spinel:

Spinel structure is usually considered as quick ionic conductor. In $\mathrm{LiMn}_{2} \mathrm{O}_{4}, \mathrm{Li}$ ions migrate by hopping straightly from one $8 a$ site to another $8 a$ site through the intermediate 16c site (8a-16c-8a) [46]. Each face of the $8 \mathrm{a}$ site is shared with a 16c site, forming a 3D diffusion path inside the structure. 
A single vacancy mechanism is adopted since the intermediate $\mathrm{O}_{h}$ sites have no coordinated metal ions sites (Figure 6b).

Different dopants significantly affect the lithium diffusion coefficient [94]. Yang et al. suggested that doping of the spinel with other transition metals, particularly with $\mathrm{Cu}$, can further reduce the barrier for Li migration, which may be attributed to the appropriate cation arrangement [94]. Nakayama et al. claimed that partially replace $\mathrm{Mn}$ with Co can improve the lithium conductivity owing to the charge disproportionation of $\mathrm{Co}^{3.5+}$ [46]. For $\mathrm{LiNi}_{0.5} \mathrm{Mn}_{1.5} \mathrm{O}_{4}$, the disordered phase has higher ionic conductivity, due to its reduced repulsive interactions among lithium ions caused by the randomly distributed Mn ions [106], and less intergrain stress as a result of the one-phase reaction upon charging [107]. In addition, local charge distribution may also influence lithium diffusion in $\mathrm{LiMn}_{2} \mathrm{O}_{4}$. Xu et al. demonstrated that $\mathrm{Mn}^{4+}$ can facilitate ion conduction [50].

In summary, Li-ion battery cathodes generally exhibit $\mathrm{Li}^{+}$diffusivities in the range of $10^{-16}$ to $10^{-8} \mathrm{~cm}^{2} \mathrm{~s}^{-1}$ at room temperature (Table 6), affected by their structural dimensionality, preparation method and measurement techniques.

Table 6. Lithium diffusion coefficients of layered and spinel Mn-based oxides.

\begin{tabular}{|c|c|c|c|c|c|}
\hline Category & Materials & $\begin{array}{l}\text { Diffusivity } \\
\left(\mathrm{cm}^{2} \mathrm{~s}^{-1}\right)\end{array}$ & Preparation Methods & $\begin{array}{c}\text { Measurement } \\
\text { Techniques }\end{array}$ & References \\
\hline \multirow{10}{*}{ Layered } & $\mathrm{Li}\left[\mathrm{Ni}_{0.5} \mathrm{Co}_{0.2} \mathrm{Mn}_{0.3}\right] \mathrm{O}_{2}$ & $\sim 1 \times 10^{-8}$ & Atomic layer deposition (ALD) & $\mathrm{CV}$ & [108] \\
\hline & $\mathrm{Li}_{0.99} \mathrm{Al}_{0.01} \mathrm{Ni}_{0.5} \mathrm{Co}_{0.2} \mathrm{Mn}_{0.3} \mathrm{O}_{2}$ & $2.41 \times 10^{-11}$ & Solid-state reaction & EIS & [109] \\
\hline & $\mathrm{Al}_{2} \mathrm{O}_{3}$-coated $\mathrm{Li}\left[\mathrm{Ni}_{0.5} \quad \mathrm{Co}_{0.2} \mathrm{Mn}_{0.3}\right] \mathrm{O}_{2}$ & $\sim 0.5 \times 10^{-8}$ & ALD & $\mathrm{CV}$ & [108] \\
\hline & $\mathrm{ZrO}_{2}$-coated Li $\left[\mathrm{Ni}_{0.5} \mathrm{Co}_{0.2} \mathrm{Mn}_{0.3}\right] \mathrm{O}_{2}$ & $1.5 \sim 2.5 \times 10^{-8}$ & ALD & $\mathrm{CV}$ & [108] \\
\hline & MgO-coated Li[ $\left[\mathrm{Ni}_{0.5} \mathrm{Co}_{0.2} \mathrm{Mn}_{0.3}\right] \mathrm{O}_{2}$ & $3 \sim 4 \times 10^{-8}$ & ALD & $\mathrm{CV}$ & [108] \\
\hline & $\mathrm{Li}_{1.2} \mathrm{Ni}_{0.13} \mathrm{Co}_{0.13} \mathrm{Mn}_{0.54} \mathrm{O}_{2}$ & $\sim 10^{-16}$ & Pulse laser deposition (PLD) method & DART-ESM & [110] \\
\hline & $\begin{array}{l}\text { Hollow hierarchical microspheres } \\
\qquad \mathrm{Li}_{1.2} \mathrm{Ni}_{0.13} \mathrm{Co}_{0.13} \mathrm{Mn}_{0.54} \mathrm{O}_{2}\end{array}$ & $1.34 \times 10^{-15}$ & Molten salt method & EIS & [111] \\
\hline & $\mathrm{Li}_{1.17} \mathrm{Ni}_{0.23} \mathrm{Mn}_{0.58} \mathrm{Mg}_{0.02} \mathrm{O}_{2}$ & $2.10 \times 10^{-15}$ & Co-precipitation method & EIS & [112] \\
\hline & $\begin{array}{c}\text { Graphene@CNTs-modified } \\
\mathrm{Li}_{1.165} \mathrm{Ni}_{0.167} \mathrm{Co}_{0.167} \mathrm{Mn}_{0.501} \mathrm{O}_{2}\end{array}$ & $\sim 10^{-9}$ & Ultrasonic-assisted co-precipitation method & $\mathrm{CV}$ & [113] \\
\hline & Carbon-coated $\mathrm{Li}_{1.2} \mathrm{Co}_{0.4} \mathrm{Mn}_{0.4} \mathrm{O}_{2}$ & $10^{-12} \sim 10^{-9}$ & Self-combustion reaction (SCR) & GITT & [114] \\
\hline \multirow{13}{*}{ Spinel } & $\mathrm{LiNi}_{0.5} \mathrm{Mn}_{1.5} \mathrm{O}_{4}$ (ordered) & $\sim 5 \times 10^{-10}$ & Acquired from corporation & GITT & [106] \\
\hline & $\mathrm{LiNi}_{0.5} \mathrm{Mn}_{1.5} \mathrm{O}_{4}$ (ordered) & $10^{-9} \sim 10^{-8}$ & - & $\begin{array}{l}\text { Theoretical } \\
\text { studies }\end{array}$ & [115] \\
\hline & thin film $\mathrm{LiNi}_{0.5} \mathrm{Mn}_{1.5} \mathrm{O}_{4}$ (ordered) & $10^{-12} \sim 10^{-10}$ & Electrostatic spray deposition technique & EIS & [116] \\
\hline & $\mathrm{LiNi}_{0.5} \mathrm{Mn}_{1.5} \mathrm{O}_{4}$ (ordered) & $1.252 \times 10^{-14}$ & Co-precipitation method & EIS & [107] \\
\hline & thin film $\mathrm{LiNi}_{0.5} \mathrm{Mn}_{1.5} \mathrm{O}_{4}$ (ordered) & $10^{-12} \sim 10^{-10}$ & PLD & PITT & [117] \\
\hline & $\mathrm{LiNi}_{0.5} \mathrm{Mn}_{1.5} \mathrm{O}_{4}$ (disordered) & $\sim 10^{-9}$ & Acquired from corporation & GITT & [106] \\
\hline & thin film LiNi $\mathrm{Li}_{0.5} \mathrm{Mn}_{1.5} \mathrm{O}_{4-\delta}$ (disordered) & $10^{-12} \sim 10^{-10}$ & PLD & PITT & [118] \\
\hline & $\mathrm{LiNi}_{0.25} \mathrm{Cu}_{0.25} \mathrm{Mn}_{1.5} \mathrm{O}_{4}$ & $10^{-14} \sim 10^{-13}$ & Sol-gel method & PITT & [94] \\
\hline & $\mathrm{LiNi}_{0.45} \mathrm{Cu}_{0.05} \mathrm{Mn}_{1.5} \mathrm{O}_{4}$ & $\sim 10^{-9}$ & Sol-gel method & GITT & [119] \\
\hline & $\mathrm{LiNi}_{0.45} \mathrm{Co}_{0.1} \mathrm{Mn}_{1.45} \mathrm{O}_{4}$ & $8 \times 10^{-12} \sim 7 \times 10^{-10}$ & PVP-combustion method & PITT & [120] \\
\hline & $\begin{array}{c}\mathrm{LiNi}_{0.5} \mathrm{Mn}_{1.5} \mathrm{O}_{4} / \mathrm{Li}_{7} \mathrm{La}_{3} \mathrm{Zr}_{2} \mathrm{O}_{12} \text { composite } \\
\text { cathode }\end{array}$ & $1.83 \times 10^{-10}$ & Spray drying method & $\mathrm{CV}$ & {$[121]$} \\
\hline & $\mathrm{SiO}_{2}$-Coated $\mathrm{LiNi}_{0.5} \mathrm{Mn}_{1.5} \mathrm{O}_{4}$ (ordered) & $1.437 \times 10^{-14}$ & Co-precipitation method & EIS & [107] \\
\hline & $\begin{array}{l}\text { Polyimide-Coated } \mathrm{LiNi}_{0.5} \mathrm{Mn}_{1.5} \mathrm{O}_{4} \\
\text { (ordered) }\end{array}$ & $1.154 \times 10^{-14}$ & Co-precipitation method & EIS & {$[107]$} \\
\hline
\end{tabular}

CV: cyclic voltammetry; EIS: electrochemical impedance spectroscopy; DART-ESM: dual AC resonance tracking-electrochemical strain microscopy; GITT: galvanostatic intermittent titration; PITT: potentiostatic intermittent titration technique.

\subsubsection{The Mobility of Cations}

The mobility of cations is closely related to the phase change during cycling. For example, the layered-to-spinel transformation is energetically favored for almost all $3 \mathrm{~d}$ transition metal layered oxides, which requires the rearrangement of metal ions since all the structures share the same cubic closed-packed (ccp) oxide framework [2]. However, the transform rate varies for each $3 \mathrm{~d}$ metal, reflecting a kinetic factor in the transformation. Another example is the voltage hysteresis of Li-rich layered oxides which is caused by the migration of TM ions from TM-layers to Li-layers [73,74]. Therefore, it is necessary to discuss the mobility of cations.

Take the migration of $\mathrm{Mn}$ as an example, which occurs in the layered-/orthorhombic-LiMnO${ }_{2}$ and Li-rich layered oxides. Reed et al. [2] pointed out that the valence and electronic structure play significant roles in determining the mobility of $\mathrm{Mn}$, rather than the size effects, which can be understood by the ligand-field theory (LFT). Since the low-energy pathway for TM ion migration between $\mathrm{O}_{h}$ sites is octahedral-tetrahedral-octahedral $\left(\mathrm{O}_{h} \rightarrow \mathrm{T}_{d} \rightarrow \mathrm{O}_{h}\right)$, the change of ligand-field 
stabilization energy (LFSE) for TM ion movement between $\mathrm{O}_{h}$ and $\mathrm{T}_{\mathrm{d}}$ coordination will determine the transformation resistance $[2,4] . \mathrm{Mn}^{4+}\left(3 \mathrm{~d}^{3}\right)$ is the most stable valence in $\mathrm{O}_{\mathrm{h}}$ coordination, due to the increased energy when migrate from $\mathrm{O}_{h}\left(t_{2 g}{ }^{3}\right)$ site to $\mathrm{T}_{\mathrm{d}}\left(\mathrm{e}^{2} \mathrm{t}_{2}{ }^{1}\right)$ site (Figure 7a). $\mathrm{Mn}^{3+}$ has a reduced $\mathrm{O}_{\mathrm{h}}$ affinity comparing to $\mathrm{Mn}^{4+}$ and less $\mathrm{T}_{\mathrm{d}}$ preference than $\mathrm{Mn}^{2+}$, and thus $\triangle \mathrm{LFSE}_{\mathrm{otc} \rightarrow \text { tet }}$ has slightly positive value. However, the mobility is accelerated by the energetically favored charge disproportionation of $\mathrm{Mn}_{\mathrm{oct}}{ }^{3+}\left(\mathrm{t}_{2 \mathrm{~g}}{ }^{3} \mathrm{eg}_{\mathrm{g}}{ }^{1}\right)$, in which an additional electron transfers from the $\mathrm{e}_{\mathrm{g}}$ orbital to the $\mathrm{T}_{\mathrm{d}} \mathrm{Mn} \mathrm{t} \mathrm{t}_{2}$ orbital (Figure $7 \mathrm{~b}$ ). Besides, other factors influencing the migration of $\mathrm{Mn}$ ions include [2]: (1) the d-orbital barycenter which is sensitive to cationic ordering; (2) the number of empty $T_{d}$ sites determined by $\mathrm{Li}$ content; and (3) the amount of $\mathrm{Mn}^{2+}$ depending on the average degree of $\mathrm{Mn}$ oxidation. Considering that $\mathrm{Mn}^{4+}$ is the most stable in $\mathrm{O}_{\mathrm{h}}$ coordination comparing to $\mathrm{Mn}^{2+}$ and $\mathrm{Mn}^{3+}$, it might be desirable for $\mathrm{Mn}$ to be electrochemically cycled near +4 valence state. However, oxidize Mn above +4 is difficult and may decompose to release $\mathrm{O}_{2}$ [2]. When $\mathrm{O}_{2}$ release occurred, such as in $\mathrm{Li}_{2} \mathrm{MnO}_{3}$, the valence of $\mathrm{Mn}$ ions may be reduced as a result of the changed oxygen charge densities [14], and thus the mobility of Mn ions is changed.

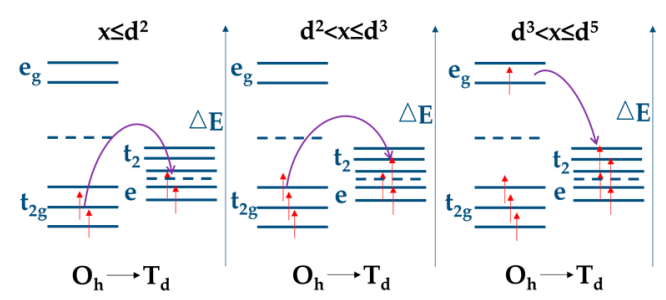

(a)

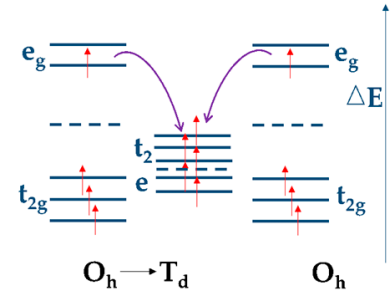

(b)

Figure 7. (a) The change of d electrons when $T M$ ions move from $\mathrm{O}_{h}$ to $\mathrm{T}_{\mathrm{d}}$ coordination. (b) Illustration of the charge disproportionation of $\mathrm{Mn}^{3+}$. (Adapted with permission from [2], Copyright 2004, American Chemical Society).

For the other $3 \mathrm{~d}$ TM ions, their $3 \mathrm{~d}$ orbitals have similar ligand-field spitting in $\mathrm{O}_{\mathrm{h}}$ or $\mathrm{T}_{\mathrm{d}}$ sites, and the magnitude of the splitting is determined by the extent of overlap between TM $d$ and oxygen $p$ states. Through similar calculation, Reed et al. [2] found that $\mathrm{Ti}^{4+}$ can easily move between $\mathrm{O}_{\mathrm{h}}$ and $\mathrm{T}_{\mathrm{d}}$ coordination attributed to its empty d band; for $\mathrm{Cr}^{\mathrm{x}+}(\mathrm{x}=3 \sim 4), \mathrm{Co}^{\mathrm{y}+}(\mathrm{y}=3 \sim 4)$ and $\mathrm{Ni}^{\mathrm{z}+}(\mathrm{z}=3 \sim 4)$, a strong preference for $\mathrm{O}_{\mathrm{h}}$ coordination is shown. Moreover, in the charged oxide cathodes, the mobility of metal cations decreases in the order $\mathrm{Ni}^{4+}>\mathrm{Co}^{\mathrm{x+}}(3.5<\mathrm{x}<4)>\mathrm{Mn}^{4+}[4]$.

\section{Conclusions}

Mn-based cathodes are being pursued as cathodes for next generation Li-ion batteries, due to their native advantages of high abundance, inexpensive price, acceptable activity, and low toxicity. This report has provided a brief account of thermodynamic and kinetic understanding on Mn-based intercalation cathode materials. Generally, for Mn-based cathodes, the Jahn-Teller effect caused by $\mathrm{Mn}^{3+}\left(\mathrm{t}_{2 \mathrm{~g}}{ }^{3} \mathrm{eg}^{1}\right)$, the disproportionation reaction of $\mathrm{Mn}^{3+}$, the mobility of $\mathrm{Mn}$ ions in different valence states $\left(\mathrm{Mn}^{2+}>\mathrm{Mn}^{3+}>\mathrm{Mn}^{4+}\right)$, and the structural features significantly influence their behavior in electrochemical processes. Besides, thermodynamic and kinetic factors should be considered equally in relatively structural stability, phase transformations, electrical and ionic conductivity, etc. These insights are valuable in the design of new cathode materials for the next generation $\mathrm{Li}$-ion batteries.

Acknowledgments: This work was financially supported by the National Science Foundation of China (Nos. 51234003 and 51374138).

Conflicts of Interest: The authors declare no conflict of interest. 


\section{References}

1. Freire, M.; Kosova, N.V.; Jordy, C.; Chateigner, D.; Lebedev, O.I.; Maignan, A.; Pralong, V. A new active Li-Mn-O compound for high energy density Li-ion batteries. Nat. Mater. 2016, 15, 173-177. [CrossRef] [PubMed]

2. Reed, J.; Ceder, G. Role of electronic structure in the susceptibility of metastable transition-metal oxide structures to transformation. Chem. Rev. 2004, 104, 4513-4534. [CrossRef] [PubMed]

3. Ammundsen, B.; Paulsen, J. Novel lithium-ion cathode materials based on layered manganese oxides. Adv. Mater. 2001, 13, 943-956. [CrossRef]

4. Yu, X.; Hu, E.; Bak, S.; Zhou, Y.-N.; Yang, X.-Q. Strategies to curb structural changes of lithium/transition metal oxide cathode materials \& the changes' effects on thermal \& cycling stability. Chin. Phys. B 2016, 25, 018205.

5. Noh, H.-J.; Youn, S.; Yoon, C.S.; Sun, Y.-K. Comparison of the structural and electrochemical properties of layered $\mathrm{Li}\left[\mathrm{Ni}_{\mathrm{x}} \mathrm{Co}_{\mathrm{y}} \mathrm{Mn}_{\mathrm{z}}\right] \mathrm{O}_{2}(\mathrm{x}=1 / 3,0.5,0.6,0.7,0.8$ and 0.85$)$ cathode material for lithium-ion batteries. J. Power Source 2013, 233, 121-130. [CrossRef]

6. Manthiram, A.; Knight, J.C.; Myung, S.-T.; Oh, S.-M.; Sun, Y.-K. Nickel-rich and lithium-rich layered oxide cathodes: progress and perspectives. Adv. Energy Mater. 2016, 6, 1501010. [CrossRef]

7. Peng, J.Y.; Zu, C.; Li, H. Fundamental scientific aspects of lithium batteries (I) -thermodynamic calculations of theoretical energy densities of chemical energy storage systems. Energy Storage Sci. Technol. 2013, 2, 55-62.

8. Andre, D.; Kim, S.-J.; Lamp, P.; Lux, S.F.; Maglia, F.; Paschos, O.; Stiaszny, B. Future generations of cathode materials: an automotive industry perspective. J. Mater. Chem. A 2015, 3, 6709-6732. [CrossRef]

9. Kim, J.-S.; Johnson, C.S.; Vaughey, J.T.; Thackeray, M.M.; Hackney, S.A.; Yoon, W.; Grey, C.P. Electrochemical and structural properties of $x \mathrm{Li}_{2} \mathrm{M}^{\prime} \mathrm{O}_{3} \cdot(1-\mathrm{x}) \mathrm{LiMn}_{0.5} \mathrm{Ni}_{0.5} \mathrm{O}_{2}$ electrodes for lithium batteries $\left(\mathrm{M}^{\prime}=\mathrm{Ti}, \mathrm{Mn}, \mathrm{Zr}\right.$; $0 \leq \mathrm{x} \leq$ 0.3). Chem. Mater. 2004, 16, 1996-2006. [CrossRef]

10. Gummow, R.J.; de Kock, A.; Thackeray, M.M. Improved capacity retention in rechargeable $4 \mathrm{~V}$ lithium/lithium-manganese oxide (spinel) cells. Solid State Ion. 1994, 69, 59-67. [CrossRef]

11. Markovsky, B.; Talyossef, Y.; Salitra, G.; Aurbach, D.; Kim, H.-J.; Choi, S. Cycling and storage performance at elevated temperatures of $\mathrm{LiNi}_{0.5} \mathrm{Mn}_{1.5} \mathrm{O}_{4}$ positive electrodes for advanced $5 \mathrm{~V}$ Li-ion batteries. Electrochem. Commun. 2004, 6, 821-826. [CrossRef]

12. Wang, L.; Maxisch, T.; Ceder, G. A first-principles approach to studying the thermal stability of oxide cathode materials. Chem. Mater. 2007, 19, 543-552. [CrossRef]

13. Gu, M.; Belharouak, I.; Zheng, J.; Wu, H.; Xiao, J.; Genc, A.; Amine, K.; Thevuthasan, S.; Baer, D.R.; Zhang, J.G.; et al. Formation of the spinel phase in the layered composite cathode used in Li-ion batteries. ACS Nano 2013, 7, 760-767. [CrossRef] [PubMed]

14. Xu, B.; Fell, C.R.; Chi, M.; Meng, Y.S. Identifying surface structural changes in layered Li-excess nickel manganese oxides in high voltage lithium ion batteries: A joint experimental and theoretical study. Energy Environ. Sci. 2011, 4, 2223. [CrossRef]

15. Stroukoff, K.R.; Manthiram, A. Thermal stability of spinel $\mathrm{Li}_{1.1} \mathrm{Mn}_{1.9-\mathrm{y}} \mathrm{M}_{\mathrm{y}} \mathrm{O}_{4-\mathrm{z}} \mathrm{F}_{\mathrm{z}}(\mathrm{M}=\mathrm{Ni}, \mathrm{Al}$, and Li, $0 \leq \mathrm{y} \leq 0.3$, and $0 \leq \mathrm{z} \leq 0.2$ ) cathodes for lithium ion batteries. J. Mater. Chem. 2011, 21, 10165. [CrossRef]

16. Belharouak, I.; Lu, W.; Vissers, D.; Amine, K. Safety characteristics of $\mathrm{Li}\left(\mathrm{Ni}_{0.8} \mathrm{Co}_{0.15} \mathrm{Al}_{0.05}\right) \mathrm{O}_{2}$ and $\mathrm{Li}\left(\mathrm{Ni}_{1 / 3} \mathrm{Co}_{1 / 3} \mathrm{Mn}_{1 / 3}\right) \mathrm{O}_{2}$. Electrochem. Commun. 2006, 8, 329-335. [CrossRef]

17. Nam, K.-W.; Bak, S.-M.; Hu, E.; Yu, X.; Zhou, Y.; Wang, X.; Wu, L.; Zhu, Y.; Chung, K.-Y.; Yang, X.-Q. Combining in situ synchrotron $\mathrm{X}$-ray diffraction and absorption techniques with transmission electron microscopy to Study the origin of thermal instability in overcharged cathode materials for lithium-Ion batteries. Adv. Funct. Mater. 2013, 23, 1047-1063. [CrossRef]

18. Liu, G.Q.; Wen, L.; Liu, Y.M. Spinel $\mathrm{LiNi}_{0.5} \mathrm{Mn}_{1.5} \mathrm{O}_{4}$ and its derivatives as cathodes for high-voltage Li-ion batteries. J. Solid State Electrochem. 2010, 14, 2191-2202. [CrossRef]

19. Park, S.B.; Eom, W.S.; Cho, W.I.; Jang, H. Electrochemical properties of $\mathrm{LiNi}_{0.5} \mathrm{Mn}_{1.5} \mathrm{O}_{4}$ cathode after $\mathrm{Cr}$ doping. J. Power Source 2006, 159, 679-684. [CrossRef]

20. Thackeray, M.M.; Kang, S.-H.; Johnson, C.S.; Vaughey, J.T.; Benedek, R.; Hackney, S.A. $\mathrm{Li}_{2} \mathrm{MnO}_{3}$-stabilized $\mathrm{LiMO}_{2}(\mathrm{M}=\mathrm{Mn}, \mathrm{Ni}, \mathrm{Co})$ electrodes for lithium-ion batteries. J. Mater. Chem. 2007, 17, 3112-3125. [CrossRef]

21. Kraytsberg, A.; Ein-Eli, Y. Higher, stronger, better... A review of 5 Volt cathode materials for advanced lithium-ion batteries. Adv. Energy Mater. 2012, 2, 922-939. [CrossRef] 
22. Wang, Q.S.; Sun, J.H.; Chen, C.H. Thermal stability of delithiated $\mathrm{LiMn}_{2} \mathrm{O}_{4}$ with electrolyte for lithium-ion batteries. J. Electrochem. Soc. 2007, 154, A263-A267. [CrossRef]

23. Xu, G.; Liu, Z.; Zhang, C.; Cui, G.; Chen, L. Strategies for improving the cyclability and thermo-stability of $\mathrm{LiMn}_{2} \mathrm{O}_{4}$-based batteries at elevated temperatures. J. Mater. Chem. A 2015, 3, 4092-4123. [CrossRef]

24. Mishra, S.K.; Ceder, G. Structural stability of lithium manganese oxides. Phys. Rev. B 1999, 59, 6120-6130. [CrossRef]

25. Armstrong, A.R.; Bruce, P.G. Synthesis of layered $\mathrm{LiMnO}_{2}$ as an electrode for rechargeable lithium batteries. Nature 1996, 381, 499. [CrossRef]

26. Yin, S.C.; Rho, Y.H.; Swainson, I.; Nazar, L.F. X-ray/Neutron diffraction and electrochemical studies of lithium de/re-intercalation in $\mathrm{Li}_{1-\mathrm{x}} \mathrm{Co}_{1 / 3} \mathrm{Ni}_{1 / 3} \mathrm{Mn}_{1 / 3} \mathrm{O}_{2}(\mathrm{x}=0 \rightarrow 1)$. Chem. Mater. 2006, 18, 1901-1910. [CrossRef]

27. Doeff, M.M. Battery Cathodes. In Batteries for Sustainability: Selected Entries from the Encyclopedia of Sustainability Science and Technology; Brodd, R.J., Ed.; Springer: New York, NY, USA, 2013; pp. 5-49.

28. Ma, C.; Lv, Y.C.; Li, H. Fundamental scientific aspects of lithium batteries (VII)-Positive electrode materials. Energy Storage Sci. Technol. 2014, 3, 53-65.

29. Rozier, P.; Tarascon, J.M. Review-Li-rich layered oxide cathodes for next-generation Li-Ion batteries: Chances and challenges. J. Electrochem. Soc. 2015, 162, A2490-A2499. [CrossRef]

30. Shi-xi, Z.; Han-xing, L.; Shi-xi, O.; Qiang, L. Synthesis and performance of $\mathrm{LiMnO}_{2}$ as cathodes for Li-ion batteries. J. Wuhan Univ. Technol.Mater. Sci. Ed. 2003, 18, 5-8. [CrossRef]

31. Wu, E.J.; Tepesch, P.D.; Ceder, G. Size and charge effects on the structural stability of $\mathrm{LiMO}_{2}(\mathrm{M}=$ transition metal) compounds. Philos. Mag. Part B 1998, 77, 1039-1047. [CrossRef]

32. Goodenough, J.B. On the influence of $3 \mathrm{~d}^{4}$ ions on the magnetic and crystallographic properties of magnetic oxides. J. Phys. Radium 1959, 20, 155-159. [CrossRef]

33. Jang, Y.I.; Moorehead, W.D.; Chiang, Y.M. Synthesis of the monoclinic and orthorhombic phases of $\mathrm{LiMnO}_{2}$ in oxidizing atmosphere. Solid State Ion. 2002, 149, 201-207. [CrossRef]

34. Jang, Y.-I.; Chiang, Y.-M. Stability of the monoclinic and orthorhombic phases of $\mathrm{LiMnO}_{2}$ with temperature, oxygen partial pressure, and Al doping. Solid State Ion. 2000, 130, 53-59. [CrossRef]

35. Whitfield, P.; Davidson, I.; Cranswick, L.; Swainson, I.; Stephens, P. Investigation of possible superstructure and cation disorder in the lithium battery cathode material $\mathrm{LiMn}_{1 / 3} \mathrm{Ni}_{1 / 3} \mathrm{Co}_{1 / 3} \mathrm{O}_{2}$ using neutron and anomalous dispersion powder diffraction. Solid State Ion. 2005, 176, 463-471. [CrossRef]

36. Tsai, Y.W.; Hwang, B.J.; Ceder, G.; Sheu, H.S.; Liu, D.G.; Lee, J.F. In-situ X-ray absorption spectroscopic study on variation of electronic transitions and local structure of $\mathrm{LiNi}_{1 / 3} \mathrm{Co}_{1 / 3} \mathrm{Mn}_{1 / 3} \mathrm{O}_{2}$ cathode material during electrochemical cycling. Chem. Mater. 2005, 17, 3191-3199. [CrossRef]

37. Zeng, D.; Cabana, J.; Bréger, J.; Yoon, W.-S.; Grey, C.P. Cation ordering in $\mathrm{Li}\left[\mathrm{Ni}_{\mathrm{x}} \mathrm{Mn}_{\mathrm{x}} \mathrm{Co}_{(1-2 \mathrm{x})}\right] \mathrm{O}_{2}$-layered cathode materials: A nuclear magnetic resonance (NMR), pair distribution function, X-ray absorption spectroscopy, and electrochemical study. Chem. Mater. 2007, 19, 6277-6289. [CrossRef]

38. Cahill, L.S.; Yin, S.C.; Samoson, A.; Heinmaa, I.; Nazar, L.F.; Goward, G.R. ${ }^{6}$ Li NMR studies of cation disorder and transition metal ordering in $\mathrm{Li}\left[\mathrm{Ni}_{1 / 3} \mathrm{Mn}_{1 / 3} \mathrm{Co}_{1 / 3}\right] \mathrm{O}_{2}$ using ultrafast magic angle spinning. Chem. Mater. 2005, 17, 6560-6566. [CrossRef]

39. Koyama, Y.; Tanaka, I.; Adachi, H.; Makimura, Y.; Ohzuku, T. Crystal and electronic structures of superstructural $\mathrm{Li}_{1-x}\left[\mathrm{Co}_{1 / 3} \mathrm{Ni}_{1 / 3} \mathrm{Mn}_{1 / 3}\right] \mathrm{O}_{2}(0 \leq \mathrm{x} \leq 1)$. J. Power Source 2003, 119-121, 644-648. [CrossRef]

40. Yabuuchi, N. Solid-state redox reaction of oxide ions for rechargeable batteries. Chem. Lett. 2017, 46, 412-422. [CrossRef]

41. Strobel, P.; Lambert-Andron, B. Crystallographic and magnetic structure of $\mathrm{Li}_{2} \mathrm{MnO}_{3}$. J. Solid State Chem. 1988, 75, 90-98. [CrossRef]

42. Rossouw, M.H.; Thackeray, M.M. Lithium manganese oxides from $\mathrm{Li}_{2} \mathrm{MnO}_{3}$ for rechargeable lithium battery applications. Mater. Res. Bull. 1991, 26, 463-473. [CrossRef]

43. Rossouw, M.H.; Liles, D.C.; Thackeray, M.M. Synthesis and structural characterization of a novel layered lithium manganese oxide, $\mathrm{Li}_{0.36} \mathrm{Mn}_{0.91} \mathrm{O}_{2}$, and Its lithiated derivative, $\mathrm{Li}_{1.09} \mathrm{Mn}_{0.91} \mathrm{O}_{2}$. J. Solid State Chem. 1993, 104, 464-466. [CrossRef]

44. Zheng, J.; Gu, M.; Genc, A.; Xiao, J.; Xu, P.; Chen, X.; Zhu, Z.; Zhao, W.; Pullan, L.; Wang, C.; et al. Mitigating Voltage Fade in Cathode Materials by Improving the Atomic Level Uniformity of Elemental Distribution. Nano Lett. 2014, 14, 2628-2635. [CrossRef] [PubMed] 
45. Xiang, X.; Knight, J.C.; Li, W.; Manthiram, A. Understanding the influence of composition and synthesis temperature on oxygen loss, reversible capacity, and electrochemical behavior of $x \mathrm{Li}_{2} \mathrm{MnO}_{3}-(1-\mathrm{x}) \mathrm{LiCoO}_{2}$ cathodes in the first cycle. J. Phys. Chem. C 2014, 118, 23553-23558. [CrossRef]

46. Nakayama, M.; Kaneko, M.; Wakihara, M. First-principles study of lithium ion migration in lithium transition metal oxides with spinel structure. Phys. Chem. Chem. Phys. 2012, 14, 13963-13970. [CrossRef] [PubMed]

47. Longo, R.C.; Kong, F.T.; Kc, S.; Park, M.S.; Yoon, J.; Yeon, D.H.; Park, J.H.; Doo, S.G.; Cho, K. Phase stability of Li-Mn-O oxides as cathode materials for Li-ion batteries: insights from ab initio calculations. Phys. Chem. Chem. Phys. 2014, 16, 11218-11227. [CrossRef] [PubMed]

48. Wen, J.-W.; Zhang, D.-W.; Zang, Y.; Sun, X.; Cheng, B.; Ding, C.-X.; Yu, Y.; Chen, C.-H. One-step synthesis and effect of heat-treatment on the structure and electrochemical properties of $\mathrm{LiNi}_{0.5} \mathrm{Mn}_{1.5} \mathrm{O}_{4}$ cathode material for lithium-ion batteries. Electrochim. Acta 2014, 133, 515-521. [CrossRef]

49. Van der Ven, A.; Bhattacharya, J.; Belak, A.A. Understanding Li diffusion in Li-intercalation compounds. Acc. Chem. Res. 2013, 46, 1216-1225. [CrossRef] [PubMed]

50. Xu, B.; Meng, S. Factors affecting Li mobility in spinel $\mathrm{LiMn}_{2} \mathrm{O}_{4}-\mathrm{A}$ first-principles study by GGA and GGA+U methods. J. Power Source 2010, 195, 4971-4976. [CrossRef]

51. Ceder, G.; Aydinol, M.K.; Kohan, A.F. Application of first-principles calculations to the design of rechargeable Li-batteries. Comput. Mater. Sci. 1997, 8, 161-169. [CrossRef]

52. Vitins, G.; West, K. Lithium intercalation into layered $\mathrm{LiMnO}_{2}$. J. Electrochem. Soc. 1997, 144, $2587-2592$. [CrossRef]

53. Chen, Z.; Zhang, C.; Zhang, Z.; Li, J. Correlation of intercalation potential with d-electron configurations for cathode compounds of lithium-ion batteries. Phys. Chem. Chem. Phys. 2014, 16, 13255-13261. [CrossRef] [PubMed]

54. Masquelier, C.; Croguennec, L. Polyanionic (phosphates, silicates, sulfates) frameworks as electrode materials for rechargeable Li (or Na) batteries. Chem. Rev. 2013, 113, 6552-6591. [CrossRef] [PubMed]

55. Saubanère, M.; McCalla, E.; Tarascon, J.M.; Doublet, M.L. The intriguing question of anionic redox in high-energy density cathodes for Li-ion batteries. Energy Environ. Sci. 2016, 9, 984-991. [CrossRef]

56. Hy, S.; Liu, H.; Zhang, M.; Qian, D.; Hwang, B.-J.; Meng, Y.S. Performance and design considerations for lithium excess layered oxide positive electrode materials for lithium ion batteries. Energy Environ. Sci. 2016, 9, 1931-1954. [CrossRef]

57. Seo, D.-H.; Lee, J.; Urban, A.; Malik, R.; Kang, S.; Ceder, G. The structural and chemical origin of the oxygen redox activity in layered and cation-disordered Li-excess cathode materials. Nat. Chem. 2016, 8, 692-697. [CrossRef] [PubMed]

58. Luo, K.; Roberts, M.R.; Hao, R.; Guerrini, N.; Pickup, D.M.; Liu, Y.S.; Edstrom, K.; Guo, J.; Chadwick, A.V.; Duda, L.C.; et al. Charge-compensation in 3d-transition-metal-oxide intercalation cathodes through the generation of localized electron holes on oxygen. Nat. Chem. 2016, 8, 684-691. [CrossRef] [PubMed]

59. Reed, J.; Ceder, G.; Van der Ven, A. Layered-to-spinel phase transition in $\mathrm{Li}_{\mathrm{x}} \mathrm{MnO}_{2}$. Electrochem. Solid St. 2001, 4, A78-A81. [CrossRef]

60. Zheng, J.; Kan, W.H.; Manthiram, A. Role of Mn content on the electrochemical properties of nickel-rich layered $\mathrm{LiNi}_{0.8-\mathrm{x}} \mathrm{Co}_{0.1} \mathrm{Mn}_{0.1+\mathrm{x}} \mathrm{O}_{2}(0.0 \leq \mathrm{x} \leq 0.08)$ cathodes for lithium-ion batteries. ACS Appl. Mater. Interfaces 2015, 7, 6926-6934. [CrossRef] [PubMed]

61. Liu, W.; Oh, P.; Liu, X.; Lee, M.-J.; Cho, W.; Chae, S.; Kim, Y.; Cho, J. Nickel-rich layered lithium transition-metal oxide for high-energy lithium-ion batteries. Angew. Chem. Int. Edit. 2015, 54, 4440-4457. [CrossRef] [PubMed]

62. Sun, Y.; Ouyang, C.; Wang, Z.; Huang, X.; Chen, L. Effect of Co content on rate performance of $\mathrm{LiMn}_{0.5-\mathrm{x}} \mathrm{Co}_{2 \mathrm{x}} \mathrm{Ni}_{0.5-\mathrm{x}} \mathrm{O}_{2}$ cathode materials for lithium-Ion batteries. J. Electrochem. Soc. 2004, 151, A504-A508. [CrossRef]

63. Ngala, J.K.; Chernova, N.A.; Ma, M.; Mamak, M.; Zavalij, P.Y.; Whittingham, M.S. The synthesis, characterization and electrochemical behavior of the layered $\mathrm{LiNi}_{0.4} \mathrm{Mn}_{0.4} \mathrm{Co}_{0.2} \mathrm{O}_{2}$ compound. J. Mater. Chem. 2004, 14, 214-220. [CrossRef]

64. Armstrong, A.R.; Holzapfel, M.; Novák, P.; Johnson, C.S.; Kang, S.-H.; Thackeray, M.M.; Bruce, P.G. Demonstrating oxygen loss and associated structural reorganization in the lithium battery cathode $\mathrm{Li}\left[\mathrm{Ni}_{0.2} \mathrm{Li}_{0.2} \mathrm{Mn}_{0.6}\right]_{2}$. J. Am. Chem. Soc. 2006, 128, 8694-8698. [CrossRef] [PubMed] 
65. Koga, H.; Croguennec, L.; Menetrier, M.; Douhil, K.; Belin, S.; Bourgeois, L.; Suard, E.; Weill, F.; Delmas, C. Reversible oxygen participation to the redox processes revealed for $\mathrm{Li}_{1.20} \mathrm{Mn}_{0.54} \mathrm{Co}_{0.13} \mathrm{Ni}_{0.13} \mathrm{O}_{2}$. J. Electrochem. Soc. 2013, 160, A786-A792. [CrossRef]

66. Lu, Z.H.; Dahn, J.R. Understanding the anomalous capacity of $\mathrm{Li} / \mathrm{Li}\left[\mathrm{Ni}_{\mathrm{x}} \mathrm{Li}_{1 / 3-2 \mathrm{x} / 3} \mathrm{Mn}_{2 / 3-\mathrm{x} / 3}\right] \mathrm{O}_{2}$ cells using in situ X-ray diffraction and electrochemical studies. J. Electrochem. Soc. 2002, 149, A815-A822. [CrossRef]

67. Boulineau, A.; Simonin, L.; Colin, J.F.; Bourbon, C.; Patoux, S. First evidence of manganese-nickel segregation and densification upon cycling in Li-rich layered oxides for lithium batteries. Nano Lett. 2013, 13, 3857-3863. [CrossRef] [PubMed]

68. Tran, N.; Croguennec, L.; Ménétrier, M.; Weill, F.; Biensan, P.; Jordy, C.; Delmas, C. Mechanisms associated with the "plateau" observed at high voltage for the overlithiated $\mathrm{Li}_{1.12}\left(\mathrm{Ni}_{0.425} \mathrm{Mn}_{0.425} \mathrm{Co}_{0.15}\right)_{0.88} \mathrm{O}_{2}$ System. Chem. Mater. 2008, 20, 4815-4825. [CrossRef]

69. Yabuuchi, N.; Yoshii, K.; Myung, S.-T.; Nakai, I.; Komaba, S. Detailed studies of a high-capacity electrode material for rechargeable batteries, $\mathrm{Li}_{2} \mathrm{MnO}_{3}-\mathrm{LiCo}_{1 / 3} \mathrm{Ni}_{1 / 3} \mathrm{Mn}_{1 / 3} \mathrm{O}_{2}$. J. Am. Chem. Soc. 2011, 133, 4404-4419. [CrossRef] [PubMed]

70. Qian, D.; Xu, B.; Chi, M.; Meng, Y.S. Uncovering the roles of oxygen vacancies in cation migration in lithium excess layered oxides. Phys. Chem. Chem. Phys. 2014, 16, 14665-14668. [CrossRef] [PubMed]

71. Wang, C.-C.; Manthiram, A. Influence of cationic substitutions on the first charge and reversible capacities of lithium-rich layered oxide cathodes. J. Mater. Chem. A 2013, 1, 10209. [CrossRef]

72. Lee, E.-S.; Manthiram, A. Smart design of lithium-rich layered oxide cathode compositions with suppressed voltage decay. J. Mater. Chem. A 2014, 2, 3932. [CrossRef]

73. Croy, J.R.; Gallagher, K.G.; Balasubramanian, M.; Long, B.R.; Thackeray, M.M. Quantifying hysteresis and voltage fade in $x \mathrm{Li}_{2} \mathrm{MnO}_{3} \cdot(1-\mathrm{x}) \mathrm{LiMn}_{0.5} \mathrm{Ni}_{0.5} \mathrm{O}_{2}$ electrodes as a function of $\mathrm{Li}_{2} \mathrm{MnO}_{3}$ content. J. Electrochem. Soc. 2014, 161, A318-A325. [CrossRef]

74. Erickson, E.M.; Schipper, F.; Penki, T.R.; Shin, J.-Y.; Erk, C.; Chesneau, F.-F.; Markovsky, B.; Aurbach, D. Review-Recent advances and remaining challenges for lithium ion battery cathodes: II. lithium-rich, $\mathrm{xLi}_{2} \mathrm{MnO}_{3} \cdot(1-\mathrm{x}) \mathrm{LiNi}_{\mathrm{a}} \mathrm{Co}_{\mathrm{b}} \mathrm{Mn}_{\mathrm{c}} \mathrm{O}_{2}$. J. Electrochem. Soc. 2017, 164, A6341-A6348. [CrossRef]

75. Dogan, F.; Long, B.R.; Croy, J.R.; Gallagher, K.G.; Iddir, H.; Russell, J.T.; Balasubramanian, M.; Key, B. Re-entrant lithium local environments and defect driven electrochemistry of Li- and Mn-rich Li-ion battery cathodes. J. Am. Chem. Soc. 2015, 137, 2328-2335. [CrossRef] [PubMed]

76. Qiu, B.; Zhang, M.; Xia, Y.; Liu, Z.; Meng, Y.S. Understanding and controlling anionic electrochemical activity in high-capacity oxides for next generation Li-Ion batteries. Chem. Mater. 2017, 29, 908-915. [CrossRef]

77. Ates, M.N.; Jia, Q.; Shah, A.; Busnaina, A.; Mukerjee, S.; Abraham, K.M. Mitigation of layered to spinel conversion of a Li-rich layered metal oxide cathode material for Li-Ion batteries. J. Electrochem. Soc. 2014, 161, A290-A301. [CrossRef]

78. Ates, M.N.; Mukerjee, S.; Abraham, K.M. A Li-rich layered cathode material with enhanced structural stability and rate capability for Li-on batteries. J. Electrochem. Soc. 2014, 161, A355-A363. [CrossRef]

79. Zheng, J.; Gu, M.; Xiao, J.; Polzin, B.J.; Yan, P.; Chen, X.; Wang, C.; Zhang, J.-G. Functioning mechanism of $\mathrm{AlF}_{3}$ coating on the Li- and Mn-rich cathode materials. Chem. Mater. 2014, 26, 6320-6327. [CrossRef]

80. Kim, D.; Sandi, G.; Croy, J.R.; Gallagher, K.G.; Kang, S.-H.; Lee, E.; Slater, M.D.; Johnson, C.S.; Thackeray, M.M. Composite 'layered-layered-spinel' cathode structures for lithium-ion batteries. J. Electrochem. Soc. 2013, 160, A31-A38. [CrossRef]

81. Long, B.R.; Croy, J.R.; Park, J.S.; Wen, J.; Miller, D.J.; Thackeray, M.M. Advances in stabilizing 'layered-layered' $\mathrm{xLi}_{2} \mathrm{MnO}_{3} \cdot(1-\mathrm{x}) \mathrm{LiMO}_{2}(\mathrm{M}=\mathrm{Mn}, \mathrm{Ni}, \mathrm{Co})$ electrodes with a spinel component. J. Electrochem. Soc. 2014, 161, A2160-A2167. [CrossRef]

82. Qiu, B.; Zhang, M.; Wu, L.; Wang, J.; Xia, Y.; Qian, D.; Liu, H.; Hy, S.; Chen, Y.; An, K.; et al. Gas-solid interfacial modification of oxygen activity in layered oxide cathodes for lithium-ion batteries. Nat. Commun. 2016, 7, 12108. [CrossRef] [PubMed]

83. Du Pasquier, A.; Blyr, A.; Courjal, P.; Larcher, D.; Amatucci, G.; Gérand, B.; Tarascon, J.M. Mechanism for limited $55^{\circ} \mathrm{C}$ storage performance of $\mathrm{Li}_{1.05} \mathrm{Mn}_{1.95} \mathrm{O}_{4}$ electrodes. J. Electrochem. Soc. 1999, 146, 428-436. [CrossRef]

84. Xia, Y.; Zhou, Y.; Yoshio, M. Capacity Fading on Cycling of 4 V Li / LiMn ${ }_{2} \mathrm{O}_{4}$ Cells. J. Electrochem. Soc. 1997, 144, 2593-2600. [CrossRef] 
85. Pieczonka, N.P.W.; Liu, Z.; Lu, P.; Olson, K.L.; Moote, J.; Powell, B.R.; Kim, J.-H. Understanding transition-metal dissolution behavior in $\mathrm{LiNi}_{0.5} \mathrm{Mn}_{1.5} \mathrm{O}_{4}$ high-voltage spinel for lithium ion batteries. J. Phys. Chem. C 2013, 117, 15947-15957. [CrossRef]

86. Gao, J.; Lv, Y.; Li, H. Fundamental scientific aspects of lithium batteries (IV): Phase transition and phase diagram (2). Energy Storage Sci. Technol. 2013, 2, 383-401.

87. Park, M.; Zhang, X.; Chung, M.; Less, G.B.; Sastry, A.M. A review of conduction phenomena in Li-ion batteries. J. Power Source 2010, 195, 7904-7929. [CrossRef]

88. Kasnatscheew, J.; Evertz, M.; Streipert, B.; Wagner, R.; Klopsch, R.; Vortmann, B.; Hahn, H.; Nowak, S.; Amereller, M.; Gentschev, A.C.; et al. The truth about the 1st cycle Coulombic efficiency of $\mathrm{LiNi}_{1 / 3} \mathrm{Co}_{1 / 3} \mathrm{Mn}_{1 / 3} \mathrm{O}_{2}$ (NCM) cathodes. Phys. Chem. Chem. Phys. 2016, 18, 3956-3965. [CrossRef] [PubMed]

89. Aydinol, M.K.; Kohan, A.F.; Ceder, G.; Cho, K.; Joannopoulos, J. Ab initio study of lithium intercalation in metal oxides and metal dichalcogenides. Am. Phys. Soc. 1997, 56, 1354-1365.

90. Liu, Y.; Fujiwara, T.; Yukawa, H.; Morinaga, M. Electronic structures of lithium manganese oxides for rechargeable lithium battery electrodes. Solid State Ion. 1999, 126, 209-218. [CrossRef]

91. Obrovac, M.N.; Gao, Y.; Dahn, J.R. Explanation for the 4.8V plateau in $\mathrm{LiCr}_{\mathrm{x}} \mathrm{Mn}_{2-\mathrm{x}} \mathrm{O}_{4}$. Phys. Rev. B 1998, 57, 5728-5733. [CrossRef]

92. Iguchi, E.; Nakamura, N.; Aoki, A. Electrical transport properties in $\mathrm{LiMn}_{2} \mathrm{O}_{4}$. Philos. Mag. Part B 2009, 78, 65-77. [CrossRef]

93. Molenda, $\mathrm{J}$. The effect of $3 \mathrm{~d}$ substitutions in the manganese sublattice on the charge transport mechanism and electrochemical properties of manganese spinel. Solid State Ion. 2004, 171, 215-227. [CrossRef]

94. Yang, M.-C.; Xu, B.; Cheng, J.-H.; Pan, C.-J.; Hwang, B.-J.; Meng, Y.S. Electronic, structural, and electrochemical properties of $\mathrm{LiNi}_{x} \mathrm{Cu}_{y} \mathrm{Mn}_{2-\mathrm{x}-\mathrm{y}} \mathrm{O}_{4}(0<\mathrm{x}<0.5,0<\mathrm{y}<0.5)$ high-voltage spinel materials. Chem. Mater. 2011, 23, 2832-2841. [CrossRef]

95. Mackrodt, W.C.; Williamson, E.A. First-principles Hartree-Fock description of the electronic structure of monoclinic C2/m Li $\mathrm{MnO}_{2}(1 \geq \mathrm{x} \geq 0)$. Philos. Mag. Part B 1998, 77, 1077-1092. [CrossRef]

96. Zhou, F.; Kang, K.; Maxisch, T.; Ceder, G.; Morgan, D. The electronic structure and band gap of $\mathrm{LiFePO}_{4}$ and $\mathrm{LiMnPO}_{4}$. Solid State Commun. 2004, 132, 181-186. [CrossRef]

97. Mehrer, H. Diffusion in Solids: Fundamentals, Methods, Materials, Diffusion-Controlled Processes; Springer: Berlin/Heidelberg, Germany, 2007.

98. Van der Ven, A.; Ceder, G. Lithium diffusion mechanisms in layered intercalation compounds. J. Power Source 2001, 97-98, 529-531. [CrossRef]

99. Morgan, D.; Van der Ven, A.; Ceder, G. Li conductivity in $\mathrm{Li}_{x} \mathrm{MPO}_{4}(\mathrm{M}=\mathrm{Mn}, \mathrm{Fe}, \mathrm{Co}, \mathrm{Ni})$ olivine materials. Electrochem. Solid State Lett. 2004, 7, A30-A32. [CrossRef]

100. Deng, Z.; Mo, Y.; Ong, S.P. Computational studies of solid-state alkali conduction in rechargeable alkali-ion batteries. NPG Asia Mater. 2016, 8, e254. [CrossRef]

101. Nakamura, T.; Sakumoto, K.; Okamoto, M.; Seki, S.; Kobayashi, Y.; Takeuchi, T.; Tabuchi, M.; Yamada, Y. Electrochemical study on $\mathrm{Mn}^{2+}$-substitution in $\mathrm{LiFePO}_{4}$ olivine compound. J. Power Source 2007, 174, 435-441. [CrossRef]

102. Urban, A.; Seo, D.-H.; Ceder, G. Computational understanding of Li-ion batteries. npj Comput. Mater. 2016, 2, 16002. [CrossRef]

103. Kang, K.; Ceder, G. Factors that affect Li mobility in layered lithium transition metal oxides. Phys. Rev. B 2006, 74. [CrossRef]

104. Urban, A.; Lee, J.; Ceder, G. The configurational space of rocksalt-type oxides for high-capacity lithium battery electrodes. Adv. Energy Mater. 2014, 4, 1400478. [CrossRef]

105. Lee, J.; Urban, A.; Li, X.; Su, D.; Hautier, G.; Ceder, G. Unlocking the potential of cation-disordered oxides for rechargeable lithium batteries. Science 2014, 343, 519-522. [CrossRef] [PubMed]

106. Amin, R.; Belharouak, I. Part-II: Exchange current density and ionic diffusivity studies on the ordered and disordered spinel $\mathrm{LiNi}_{0.5} \mathrm{Mn}_{1.5} \mathrm{O}_{4}$ cathode. J. Power Source 2017, 348, 318-325. [CrossRef]

107. Pang, W.K.; Lin, H.-F.; Peterson, V.K.; Lu, C.-Z.; Liu, C.-E.; Liao, S.-C.; Chen, J.-M. Enhanced rate-capability and cycling-stability of $5 \mathrm{~V} \mathrm{SiO}_{2}$ - and polyimide-coated cation ordered $\mathrm{LiNi}_{0.5} \mathrm{Mn}_{1.5} \mathrm{O}_{4}$ lithium-ion battery positive electrodes. J. Phys. Chem. C 2017, 121, 3680-3689. [CrossRef] 
108. Laskar, M.R.; Jackson, D.H.; Xu, S.; Hamers, R.J.; Morgan, D.; Kuech, T.F. Atomic layer deposited MgO: A lower overpotential coating for $\mathrm{Li}\left[\mathrm{Ni}_{0.5} \mathrm{Mn}_{0.3} \mathrm{Co}_{0.2}\right] \mathrm{O}_{2}$ cathode. ACS Appl. Mater Interfaces 2017, 9, 11231-11239. [CrossRef] [PubMed]

109. Li, L.; Yao, Q.; Zhu, H.; Chen, Z.; Song, L.; Duan, J. Effect of Al substitution sites on $\mathrm{Li}_{1-\mathrm{x}} \mathrm{Alx}\left(\mathrm{Ni}_{0.5} \mathrm{Co}_{0.2} \mathrm{Mn}_{0.3}\right)_{1-\mathrm{y}} \mathrm{Al}_{\mathrm{y}} \mathrm{O}_{2}$ cathode materials for lithium ion batteries. J. Alloys Compd. 2016, 686, 30-37. [CrossRef]

110. Yang, S.; Yan, B.; Wu, J.; Lu, L.; Zeng, K. Temperature-dependent lithium-ion diffusion and activation energy of $\mathrm{Li}_{1.2} \mathrm{Co}_{0.13} \mathrm{Ni}_{0.13} \mathrm{Mn}_{0.54} \mathrm{O}_{2}$ thin-film cathode at nanoscale by using electrochemical strain microscopy. ACS Appl. Mater. Interfaces 2017, 9, 13999-14005. [CrossRef] [PubMed]

111. Lou, M.; Zhong, H.; Yu, H.-T.; Fan, S.-S.; Xie, Y.; Yi, T.-F. $\mathrm{Li}_{1.2} \mathrm{Mn}_{0.54} \mathrm{Ni}_{0.13} \mathrm{Co}_{0.13} \mathrm{O}_{2}$ hollow hierarchical microspheres with enhanced electrochemical performances as cathode material for lithium-ion battery application. Electrochim. Acta 2017, 237, 217-226. [CrossRef]

112. Yi, T.F.; Li, Y.M.; Yang, S.Y.; Zhu, Y.R.; Xie, Y. Improved cycling stability and fast charge-discharge performance of cobalt-free lithium-rich oxides by magnesium-doping. ACS Appl. Mater. Interfaces 2016, 8, 32349-32359. [CrossRef] [PubMed]

113. Ma, S.; Hou, X.; Li, Y.; Ru, Q.; Hu, S.; Lam, K.-H. Performance and mechanism research of hierarchically structured Li-rich cathode materials for advanced lithium-ion batteries. J. Mater. Sci. Mater. Electron. 2016, 28, 2705-2715. [CrossRef]

114. Wang, L.; Wang, Z.-B.; Yu, F.-D.; Liu, B.-S.; Zhang, Y.; Zhou, Y.-X. Investigation on performances of $\mathrm{Li}_{1.2} \mathrm{Co}_{0.4} \mathrm{Mn}_{0.4} \mathrm{O}_{2}$ prepared by self-combustion reaction as stable cathode for lithium-ion batteries. Ceram. Int. 2016, 42, 14818-14825. [CrossRef]

115. Ma, X.; Kang, B.; Ceder, G. High rate micron-sized ordered $\mathrm{LiNi}_{0.5} \mathrm{Mn}_{1.5} \mathrm{O}_{4}$. J. Electrochem. Soc. 2010, 157, A925-A931. [CrossRef]

116. Mohamedi, M.; Makino, M.; Dokko, K.; Itoh, T.; Uchida, I. Electrochemical investigation of $\operatorname{LiNi}_{0.5} \mathrm{Mn}_{1.5} \mathrm{O}_{4}$ thin film intercalation electrodes. Electrochim. Acta 2002, 48, 79-84. [CrossRef]

117. Xia, H.; Lu, L. Li diffusion in spinel $\mathrm{LiNi}_{0.5} \mathrm{Mn}_{1.5} \mathrm{O}_{4}$ thin films prepared by pulsed laser deposition. Phys. Scr. 2007, T129, 43-48. [CrossRef]

118. Xia, H.; Meng, Y.S.; Lu, L.; Ceder, G. Electrochemical properties of nonstoichiometric $\operatorname{LiNi}_{0.5} \mathrm{Mn}_{1.5} \mathrm{O}_{4-\delta}$ thin-film electrodes prepared by pulsed laser deposition. J. Electrochem. Soc. 2007, 154, A737-A743. [CrossRef]

119. Kondracki, Ł.; Kulka, A.; Milewska, A.; Molenda, J. In-situ structural studies of manganese spinel-based cathode materials. Electrochim. Acta 2017, 227, 294-302. [CrossRef]

120. Mao, J.; Ma, M.; Liu, P.; Hu, J.; Shao, G.; Battaglia, V.; Dai, K.; Liu, G. The effect of cobalt doping on the morphology and electrochemical performance of high-voltage spinel $\mathrm{LiNi}_{0.5} \mathrm{Mn}_{1.5} \mathrm{O}_{4}$ cathode material. Solid State Ion. 2016, 292, 70-74. [CrossRef]

121. Liu, W.; Shi, Q.; Qu, Q.; Gao, T.; Zhu, G.; Shao, J.; Zheng, H. Improved Li-ion diffusion and stability of a $\mathrm{LiNi}_{0.5} \mathrm{Mn}_{1.5} \mathrm{O}_{4}$ cathode through in situ co-doping with dual-metal cations and incorporation of a superionic conductor. J. Mater. Chem. A 2017, 5, 145-154. [CrossRef]

(C) 2017 by the authors. Licensee MDPI, Basel, Switzerland. This article is an open access article distributed under the terms and conditions of the Creative Commons Attribution (CC BY) license (http:// creativecommons.org/licenses/by/4.0/). 